\title{
BASIC COMPENSATION FOR VICTIMS OF CLIMATE CHANGE
}

\author{
DANIEL A. FARBER ${ }^{\dagger}$
}

\section{INTRODUCTION}

Global climate change is the greatest environmental challenge facing the world today. The most urgent issue is how to prevent further accumulation of greenhouse gases (GHGs) that will only fuel the process. The next priority is to implement adaptive measures, limiting harm to the extent that climate change cannot be avoided. Some degree of climate change is inevitable, imposing substantial cost to society in the form of direct harm and adaptation expenses. It is not too soon to begin considering how these costs will be allocated. In particular, we should begin to consider whether some of the damages should be shifted from victims of climate change to responsible parties, such as large-scale emitters of GHGs.'

The reality is that, whatever mitigation measures are adopted, a significant degree of climate change seems unavoidable. ${ }^{2}$ The best

\footnotetext{
${ }^{\dagger}$ Sho Sato Professor of Law and Faculty Director, California Center for Environmental Law and Policy, University of California, Berkeley. I would like to thank Matt Adler, Alex Klass, Bob Rabin, and Elaine Shoben for helpful comments, along with workshop participants at Tel Aviv University.

' For the purposes of this Article, I will not undertake to review the evidence for the reality and seriousness of climate change and the role of GHG emissions in producing climate change. Readers who remain skeptical of this point might begin with Part I of the recent Stern Review from the British government. NICHOLAS STERN, STERN REview: THE ECONOMICS OF CLIMATE CHANGE 1-61 (2007). A prepublication version of the Sterm Review is available at http://www.hm-treasury.gov.uk/independent_reviews/ stern_review_economics_climate_change/stern_review_report.cfm.

${ }^{2}$ As Donald Brown describes:

Many scientists and policy makers believe that a doubling of $\mathrm{CO}_{2}$ from preindustrial levels to $560 \mathrm{ppm}$ may be unavoidable in the $21 \mathrm{st}$ century. This is so because the world's political and economic system cannot respond rapidly enough to make faster changes in some major polluting sources such as gasoline-powered automobiles or coal-fired power plants. Some environmentalists, however, believe it is still possible to stabilize GHG[s] at $450 \mathrm{ppm}$, a level that would limit the temperature increase (in addition to that which has already been caused by human activities) to 1.5 to 2 degrees $F^{\circ}$ during the next 100 years. Virtually nobody believes that it is possible to stabilize atmospheric concentrations below $450 \mathrm{ppm}$ and concentrations could continue growing after that if third world countries do not implement aggressive reduction strategies, even if the most ambitious proposal currently under consideration
} 
current estimate is that a doubling of $\mathrm{CO}_{2}$ from preindustrial levels would result in a temperature increase between $1.5^{\circ} \mathrm{C}$ and $4.5^{\circ} \mathrm{C}$ $\left(2.7^{\circ} \mathrm{F}\right.$ to $\left.8.1^{\circ} \mathrm{F}\right)$ by the end of this century. ${ }^{3}$ For this reason, even in the best-case scenario, we will be faced with a number of adverse impacts from climate change-and indeed, we are already experiencing them:

[M] any of the climate impacts identified by IPCC [Intergovernmental Panel on Climate Change] are likely to occur regardless of the nature of the international policy response. In fact, the IPCC has recently concluded that regional changes in climate, particularly increases in temperature, have already affected a diverse set of physical and biological systems in many parts of the world. Examples of observed changes caused by human releases of GHG include shrinkage of glaciers, thawing of permafrost, later freezing and earlier break-up of ice on rivers and lakes, lengthening of mid-to [sic] high-latitude growing seasons, poleward and altitudinal shifts of plants and animal ranges, declines of some plant and animal populations, and earlier flowering of trees, emerging of insects, and egg-laying in birds.

Designing a fair and efficient system of compensation for climate change damage poses great challenges. In this Article, my goal is only to start the process of thinking through these issues. In particular, I will try to show how certain kinds of injuries could be the subject of a workable compensation system. These injuries-involving changes in

were adopted. Even if all nations could have stabilized emissions in the year 2002 , the concentrations of GHGs would continue to rise and would approach $500 \mathrm{ppm}$ by the year 2100 . After that, GHG concentrations in the atmosphere would continue to rise for several hundred years before stabilization would be achieved. Even to stabilize $\mathrm{CO}_{2}$ at $1,000 \mathrm{ppm}$ will require reductions of emissions below current levels.

Donald A. Brown, The U.S. Performance in Achieving Its 1992 Earth Summit Global Warming Commitments, 32 Envtl. L. Rep. (Envtl. Law Inst.) 10,741, 10,756 (2002) (footnotes omitted). For a general survey of climate change impacts and mitigation strategies, see Matthew D. Zinn, Adapting to Climate Change: Environmental Law in a Warmer World, 34 ECOLOGY L.Q. (forthcoming 2007) (manuscript on file with author).

${ }^{3}$ Richard A. Kerr et al., Latest Forecast: Stand by for a Warmer, but Not Scorching, World, 312 SCIENCE 351, 351 (2006). For an up-to-date source of information on climate science, see RealClimate, http://www.realclimate.org (last visited May 1, 2007).

${ }^{4}$ Brown, supra note 2, at 10,756. The most recent IPCC findings are available in Intergovernmental Panel on Climate Change [IPCC], Working Group I, Climate ChanGe 2007: THE Physical SCIEnCE Basis 7-9 (2007), available at http:// ipcc-wgl.ucar.edu/wg1/Report/AR4WG1_SPM.pdf. For further details on the effects of climate change in the United States, see Camille PARMESAN \& HEctor GaLbRAITH, OBSERVED IMPACTS OF GLOBAL ClIMATE CHANGE IN THE U.S. 17-34 (2004), available at http://www.pewclimate.org/global-warming-in-depth/all_reports/observedimpacts/ index.cfm. 
basic geographic characteristics such as sea level or permafrost-are readily identifiable, do not raise the complicated causation issues that plague other potential forms of damages, and can be measured (at least roughly) in a fairly straightforward way.

In the interest of manageability, I will give only passing attention to two other important issues. The first is whether compensation of any kind is warranted in this situation. I think the answer is yes, but the question is obviously a controversial one, and I will provide only a sketch of the justification for compensation. Instead, I will be more concerned with assessing the relative attractiveness of various potential compensation claims. The objective is to identify the core claims that should be given the highest priority, assuming any claims at all are compensated. A second question is what kind of institutional process, such as litigation or an administrative compensation scheme, should be used. I will discuss the alternatives briefly in order to demonstrate that the options extend well beyond conventional litigation, but the choice between institutional forms is too complicated to address fully here. ${ }^{5}$

To provide a concrete context for the discussion, however, it may be helpful to sketch one possible compensation system. Consider an international compensation commission. The commission would receive claims from countries that have incurred adaptation expenses such as strengthening sea walls or providing alternative sources of ecosystem services to replace lost wetlands. The commission would determine which adaptation expenses were reasonable and would schedule them for compensation. Compensation might come directly from an international fund; however, an alternative payment system might be more appealing if an international trading system for GHGs were in place. In this alternative way of financing compensation, a set number of GHG allowances could be set aside for the commission's use. The commission would use these allowances to pay claims; in turn, the claimants could sell them to GHG emitters on the open market. The net effect would be that the sources doing the least to reduce their emission levels, and therefore having the greatest need to purchase additional emission permits, would indirectly provide compensation for the expenses of adaptation. Thus, a wealth transfer would take place from poorly controlled sources of GHGs to the vic-

${ }^{5}$ A third question is whether existing domestic or international laws provide a remedy for victims. This is obviously an important issue, but it is not one that I will try to resolve here. 
tims of climate change. This is only one possible implementation; for example, it is easy to imagine a similar program being established within the United States, or to envision compensation proceeding through a grant program rather than through adjudication. No plausible system will precisely measure harm and match victims with historic GHG emitters, but some form of rough justice seems achievable.

The primary goal of this Article is to identify a manageable subset of environmental harms that could be the subject of such a compensation system. Part I reviews the expected impacts of climate change and provides background on climate change litigation. Litigation provides one possible source of compensation but is not the most promising alternative. In search of guidance for providing climate change compensation, Part II examines other compensation schemes, dealing with an array of harms ranging from oil spills to terrorist acts. These compensation schemes vary in their institutional forms, in what damages are compensable, and in their treatment of causation and fault issues. Part III attempts to identify some core, highly foreseeable harms resulting from climate change and suggests methods for measuring damages. Compensation for these harms could be provided in various institutional forms. The most likely claimants would be governments rather than individuals; funding could come from assessments against GHG sources or payments by high emission nations.

My purpose is not to offer a fully matured blueprint for compensation. It is to put some basic ideas on the table and to suggest that at least part of the compensation issue is relatively manageable. In the end, the decision of whether to compensate will be driven largely by political decision makers rather than by courts or, even less likely, by scholars. Whether a large-scale compensation plan will ever be adopted, let alone when such a step might be taken, remains unclear. Even at this early stage, however, it is useful to imagine the outlines of a compensation scheme. Doing so may help focus the debate on whether or not to compensate, and it will provide a useful head start on actual programmatic design if the decision is ultimately made to provide compensation.

In a country whose political process is only now awakening to the reality of the climate change issue, it may seem almost utopian to worry about compensation. Current litigation is likely to attract more attention to the issue, as will some current endorsements of the idea in international law. If the issue is not in the forefront today, it seems safe to predict that it will be soon. 


\section{Climate Change Impacts and Litigation}

As background for discussing compensation, we need to begin by surveying some of the likely impacts of climate change that might support compensation claims. In addition, although no successful compensation claims yet exist, we need to consider the state of affairs in climate change litigation. Courts have at least begun to acknowledge the reality of harm from climate change-even in the United States, where the official governmental position is more skeptical. In particular, the Supreme Court recently held that injury from climate change is sufficiently tangible and direct to form a basis for standing." This holding is not directly relevant to compensation claims, but seems likely to foster arguments that compensation is desirable.

\section{A. Adverse Impacts of Climate Change}

In designing a basic compensation scheme, we can put aside two kinds of impacts, even though these impacts are important in considering adaptation and mitigation. First, we can put aside effects that are extremely diffuse. These are less likely to be clearly identifiable as impacts of climate change or to have identifiable groups of victims who might seek compensation. Diffuse claims are also more likely to receive lower priority than compensation of more concentrated harms. For example, individuals' increased air conditioning costs do not seem like compelling candidates for compensation.'

Second, we can also put aside for now the potential of climate "surprises"-unlikely (but possible) catastrophic events, such as the collapse of the Antarctic or Greenland ice caps (which would cause cataclysmic changes in sea level), ${ }^{8}$ or the destruction of the Gulf Stream (which would massively impact European weather). ${ }^{9}$ What-

${ }^{6}$ See Massachusetts v. EPA, 127 S. Ct. 1438 (2007). For further discussion of this case and its holding, see infra note 32.

${ }^{7}$ On the other hand, programs implementing precautions against deaths from heat waves, which might include subsidized air conditioning, do seem like plausible items for compensation.

${ }^{8}$ See Richard B. Alley et al., Ice-Sheet and Sea Level Changes, 310 SCIENCE 456, 457-60 (2005) (assessing this threat).

9 Richard A. Kerr, Confronting the Bogeyman of the Climate System, 310 SCIENCE 432 , 432 (2005) (explaining that rapid collapse of the Atlantic circulation system is now considered unlikely). Notably, current models do not include meltwater from Greenland (suggesting that such models are "not entirely realistic"). Id. at 433. Even apart from the possibility of unforeseen future increases in melt rates, the omission of this factor from models means that their sea level predictions are probably too low. 
ever compensation is offered for such extraordinary events is likely to be ad hoc and dictated largely by immediate political pressures. Moreover, calculation of compensation is likely to take a back seat to more urgent expenditures for adaptation and humanitarian aid.

At least for purposes of a first "cut" at the compensation issue, it seems better to start with mid-range impacts-impacts involving significant, but not catastrophic, costs that are likely to occur and can be clearly identified as consequences of climate change. ${ }^{10}$ This, in itself, is a large universe and likely to grow as our knowledge of climate change improves. For purposes of exploration, we can begin by identifying three major categories of harm that fit this description.

The first category involves harm to natural systems that react particularly strongly to temperature changes. There is considerable evidence, for example, that coral reefs have been damaged by climate change." At the other climatic extreme, glaciers and areas of tundra are being heavily impacted. Almost a quarter of the land in the Northern Hemisphere is situated on permafrost, much of which seems to be melting rapidly. ${ }^{12}$ Arctic Sea ice is also shrinking at a surprising rate. ${ }^{13}$ The effects of these changes on native populations may be particularly dramatic. To quote an Inuit hunter, "[o]f the people involved in global warming, I think we're on top of the list of who would be most affected. .. . Our way of life, our traditions, maybe our families. Our children may not have a future." ${ }^{14}$ It is not clear how

${ }^{10}$ In suggesting that the other possibilities be put aside in the discussion of compensation, I do not mean to imply that they should be disregarded in terms of preventative measures, whether those measures address adaptation or mitigation. Even very unlikely events are worth attending to if the costs are sufficiently high. It also should be noted that there is still considerable uncertainty at the high end of climate change estimates. The Stern Review indicates that "there is up to a one-in-five chance that the world would experience a warming in excess of $3^{\circ} \mathrm{C}$ above pre-industrial [levels] even if greenhouse gas concentrations were stabili[z]ed at today's level of $430 \mathrm{ppm} \mathrm{CO} \mathrm{CO}_{2}$." STERN, supra note 1, at 11-12. Most of the impacts discussed in this Article assume a warming of only $2^{\circ} \mathrm{C}$. In the range between $2^{\circ} \mathrm{C}$ and $3^{\circ} \mathrm{C}$, "the Earth would reach a temperature not seen since the middle Pliocene around 3 million years ago." Id. at 12.

11 See Denis Culley, Global Warming, Sea Level Rise and Tort, 8 OCEAN \& COASTAL L.J. 91, 95 \& n.35 (2002) (noting a significant decline in coral reproduction rates in warmer waters).

${ }^{12}$ Elizabeth Kolbert, Field NOtes From a CATASTROPHE: MAN, NATURE, AND ClimATE CHANGE 13-15 (2006); see also id. at 13 (noting that "[n] early every major glacier in the world is shrinking; those in Glacier National Park are retreating so quickly it has been estimated that they will vanish entirely by 2030 ").

${ }^{14} I d$. at 25. 
many of these harms should be compensable, but they surely deserve consideration. $^{15}$

The second category involves sea level rise. ${ }^{16}$ Sea level rise is one of the most predictable consequences of climate change. Apart from the unknown contribution of melting from Greenland and Antarctica, ${ }^{17}$ the simple change in the temperature of the oceans will cause thermal expansion, just as increased temperature causes the mercury in a thermometer to rise. This rise in sea level will result in loss of coastal lands, ${ }^{18}$ inundation of some estuary systems with salt water, salt water intrusions into some drinking sources, and increased exposure to flood damage. ${ }^{19}$ Sea level change may have particularly drastic effects on island populations. ${ }^{20}$ For example, the small island state of Tuvalu (perhaps best known as the home of the ".tv" Internet domain

${ }^{15}$ Other forms of ecosystem harm can also be anticipated. Biologists predict that changes in growing season will be managed by some animals (those with small size, short life cycles, and large populations), but not by larger, more long-lived animals with smaller populations, resulting in major changes in natural communities. William E. Bradshaw \& Christina M. Holzapfel, Evolutionary Response to Rapid Climate Change, 312 SCIENCE 1477, 1478 (2006). Increases in wildfires are another form of potential damage. See A.L. Westerling et al., Warming and Earlier Spring Increase Western U.S. Forest Wildfire Activity, 313 SCIENCE 940, 942-43 (2006) (describing the relationship between climate change and wildfires).

${ }^{16}$ Some scientists predict a $2 \mathrm{~m}$ increase in sea level under a "business as usual" scenario by 2100 , but only a $20 \mathrm{~cm}$ rise under an optimum regulatory strategy. E.g., K. Hasselmann et al., The Challenge of Long-Term Climate Change, 302 SCIENCE 1923, 1924 fig.1 (2003). The most recent IPCC estimates are approximately $0.2 \mathrm{~m}$ to $0.6 \mathrm{~m}$, depending on the scenario. IPCC, supra note 4, at 13 tbl.SPM-3. The effects of sea level rise are discussed in more detail in Susanne C. Moser, Climate Change and Sea-Level Rise in Maine and Hawai' $i$ : The Changing Tides of an Issue Domain, in GLOBAL. ENVIRONMENTAL ASSESSMENTS: INFORMATION AND INFLUENCE 201, 201-13 (Ronald B. Mitchell et al. eds., 2006); DAN CAYAN ET AL., Projecting Future SEA LEvel: A Report from California Climate Change Center 5-11 (Mar. 2006) (Cal. Energy Comm'n, White Paper No. CEC-500-2005-202-SF), available at http:// www.energy.ca.gov/2005publications/CEC-500-2005-202/CEC-500-2005-202-SF.PDF.

${ }^{17}$ On the potential for catastrophic melting in these areas, see STERN, supra note 1 , at $20-21$.

${ }^{18}$ See A. Barrie PitTock, Climate Change: Turning Up the Heat 264, 267-68, 278 (2005) (providing examples of land loss in areas including China, India, Pakistan, Bangladesh, and the United States).

${ }^{19}$ See Kolbert, supra note 12, at 123-24 (reporting a British governmental study indicating that what are now hundred-year floods could become routine by late in this century); see also PITTOCK, supra note 18, at 118 (stating that without adaptive measures, annual flood losses would increase from $£ 1$ billion to $£ 27$ billion in different scenarios).

${ }^{20}$ See Culley, supra note 11, at 105-07 (describing the effects of sea level rise on several island nations). 
name) is seeking ways to evacuate its entire population. ${ }^{21}$ Sea level rise could also cause dramatic losses in wetlands in the United States. ${ }^{22}$ Because the slope of coastal areas on the Atlantic and Gulf Coasts is low, a $40 \mathrm{~cm}$ rise in sea level could result in as much as $60 \mathrm{~m}$ of beach erosion, at a cost in the billions of dollars. ${ }^{23}$ To get a sense of the potential economic impact, consider the following estimates regarding sea level rise: "[A] half-meter rise in sea level would place $\$ 185$ billion of property and infrastructure in jeopardy by 2100 , and . . the financial cost of protecting all developed areas from a half-meter sea-level rise would be $\$ 50$ to $\$ 66$ billion ...." Clearly, at least over a sufficient time span, these are very serious damages.

A third category of predictable harm also relates to water. According to the British government's Stern Review, "[c] hanges in rainfall patterns and extreme weather events will lead to more severe impacts on people than that caused by warming alone." ${ }^{25}$ There are strong indications that climate change may lead to much more severe droughts in some regions. ${ }^{26}$ Many areas rely on single-source water systems that are "extremely sensitive" to climate. ${ }^{27}$ Severe stress on water supplies

21 Id. at 91-93, 106.

${ }^{22}$ See id. at 100-01 (noting that "[a] mere $50 \mathrm{~cm}$ rise in sea levels would inundate fifty per cent of America's coastal wetlands").

${ }^{23}$ David A. Grossman, Warming Up to a Not-So-Radical Idea: Tort-Based Climate Change Litigation, 28 COLUM. J. ENVTL. L. 1, 12-13 (2003).

${ }^{24}$ William E. Easterling III et al., Coping with Global Climate Change: THE ROLE OF ADAPTATION IN THE UNITED STATES 14 (2004), available at http:// www.pewclimate.org/global-warming-in-depth/all_reports/adaptation/index.cfm. This estimate may be on the high side, but even if we discount by a factor of two, the figures are still impressive. On the other hand, given the Hurricane Katrina experience, we may be entitled to wonder whether flood control systems will necessarily be effective.

${ }^{25}$ STERN, supra note 1 , at 17.

${ }^{26}$ See, e.g., KOLBERT, supra note 12, at 108-18 (noting the "Rocky Mountain states and California" as likely candidates in the United States); Carl T. Hall, Global Warming Study Forecasts More Water Shortages, S.F. CHRON., Nov. 17, 2005, at A4, available at http://www.sfgate.com/cgi-bin/article.cgi?file=/c/a/2005/11/17/ MNG4EPHK51.DTL\&hw=Global+Warm; Michael McCarthy, The Century of Drought, INDEPENDENT (London), Oct. 4, 2006, at 1; Richard M. Adams \& Dannele E. Peck, Drought and Climate Change: Implications for the West 3 (Dec. 2002) (unpublished manuscript, on file with author), available at http://www.economics.noaa.gov/ library/documents/benefits_of_weather_and_climate_forecasts/drought-climate_ change-implications_for_west.doc.

${ }^{27}$ Kenneth D. Frederick, Water Resources and Climate Change, in CLIMATE CHANGE ECONOMICS AND POLICY 67, 68-69 (Michael A. Toman ed., 2001). 
is also a possibility in some parts of the world, such as Africa ${ }^{28}$ and Australia. $^{29}$ In California, shifts in seasonal precipitation patterns could reduce the availability of water during the summer growing season. ${ }^{30}$ Increases in flooding are also likely to be significant in some areas." It may be difficult to tie any one year of drought or a particular flood to climate change, but dealing with these threats will clearly involve significant adaptation costs.

All of these damages involve impacts on basic geography in the form of diminished coastlines, available water, glaciers, and tundra. In most instances, rather than turning on the nuances of climate change models, these changes seem quite predictable. Because we are focusing on the context of compensation, we do not need to know with any certainty that these effects exist. If they are sufficiently likely, precautionary measures may be warranted, for which compensation payments may be appropriate. If they actually take place, they can be linked retrospectively with climate change because they all involve sharp deviations from clear historical patterns. These are changes in the sorts of local conditions one might expect to see in an atlas or other geographic reference.

These "geographic damages," as we might call them, clearly do not exhaust the universe of harm from climate change or of potential damage claims. Rather, they are something like the core of potential damages. If we can map out a compensation system for these claims, we can later consider how to expand it to cover other forms of damages.

\section{B. Current Efforts To Obtain Compensation}

Climate change litigation of various kinds is clearly on the increase, and the trend is to hold that potential damage from climate change is a legally cognizable injury. ${ }^{32}$ Although the favorable deci-

${ }^{28}$ PITTOCK, supra note 18, at 253-54. Note also that "[p]otential increases in the frequency and intensity of drought across subhumid Africa are likely to increase desertification." $I d$. at 255 .

${ }^{29} I d$. at 256-57. China may be vulnerable to drought increases as well. Id. at 263.

${ }^{30} I d$. at $278-79$.

${ }^{31}$ For the most up-to-date information on how climate change will affect severe weather events, see National Climatic Data Center, Extreme Weather and Climate Events, http://www.ncdc.noaa.gov/oa/climate/severeweather/extremes.html (last visited May 1, 2007).

${ }^{32}$ See Massachusetts v. EPA, 127 S. Ct. 1438, 1462-63 (2007) (holding that plaintiffs did have standing to sue, and that the EPA, despite the agency's objections, does have 
sions have involved issues of standing or administrative action rather than liability for damages, scholars have begun to discuss the damages issue in earnest. ${ }^{33}$

authority to regulate GHG emissions from motor vehicles), reversing and remanding 415 F.3d 50, 54-56 (D.C. Cir. 2005) (noting that defendant EPA questioned standing only on the basis of causation and redressability, not injury, and proceeding to the merits as in statutory standing cases); Nw. Envtl. Def. Ctr. v. Owens Corning Corp., 434 F. Supp. 2d 957, 971 (D. Or. 2006) (finding that potential victims of climate change have standing); Friends of the Earth, Inc. v. Watson, No. C 024106 JSW, 2005 WL 2035596, at *8 (N.D. Cal. Aug. 23, 2005) (same); cf. In re Quantification of Envtl. Costs, 578 N.W.2d 794, 796-97, 800 (Minn. Ct. App. 1998) (upholding a state agency's quantification of harm from $\mathrm{CO}_{2}$ emissions). But see Connecticut v. Am. Elec. Power Co., 406 F. Supp. 2d 265, 274 (S.D.N.Y. 2005) (finding that public nuisance actions against utilities "present non-justiciable political questions that are consigned to the political branches, not the Judiciary").

At the international level, see Australian Conservation Foundation v. Minister for Planning (2004) VCAT 2029 (Victorian Civil \& Admin. Trib.) (Austl.), available at http://www.austlii.edu.au/au/cases/vic/VCAT/2004/2029.html (holding that the impact of GHG emissions must be taken into account in the company's planning decisions); Gbemre v. Shell Petroleum Development Co. Nigeria Ltd., [Nov. 14, 2005], No. FHC/B/CS/53/05 (F.H.C.) (Nigeria), available at http://www.climatelaw.org/ media/gas.flaring.suit.nov2005/ni.shell.nov05.judgment.pdf (condemning, as violative of fundamental human rights, companies' natural gas flaring).

Section 601 of the RESTATEMENT (THIRD) OF FOREIGN RELATIONS LAW (1987) states that a nation "is obligated to take such measures as may be necessary, to the extent practicable under the circumstances, to ensure that activities within its jurisdiction or control ... are conducted so as not to cause significant injury to the environment of another state." This principle is based on the famous Trail Smelter Case (U.S. v. Can.), 3 R. Int'l Arb. Awards 1906 (1941). In that case, the panel decided that

no State has the right to use or permit the use of its territory in such a manner as to cause injury by fumes in or to the territory of another or the properties or persons therein, when the case is of serious consequence and the injury is established by clear and convincing evidence.

Id. at 1965. The decision references both international principles and U.S. common law. Id. at 1963-65. A claim based on the Trail Smelter principle has been filed against the United States by Inuit representatives in the Inter-American Commission on $\mathrm{Hu}$ man Rights. See Petition to the Inter-American Commission on Human Rights Seeking Relief from Violations Resulting from Global Warming Caused by Acts and Omissions of the United States 5 (Dec. 7, 2005), available at $\mathrm{http} / / /$ www.ciel.org/Publications/ ICC_Petition_7Dec05.pdf. A summary of this and other recent litigation can be found in ROBERT MELTZ, GLOBAl WaRming: The LITIGATION HEATS UP 18 (Cong. Research Serv. Rep. RL32764, April 3, 2006).

${ }^{39}$ For such discussions, see Grossman, supra note 23, at 16-22; Vincent S. Oleszkiewicz \& Douglas B. Sanders, The Advent of Climate Change Litigation Against Corporate Defendants, 27 INT'L ENV'T REP. 936, 940-41 (2004); Hari M. Osofsky, The Geography of Climate Change Litigation: Implications for Transnational Regulatory Governance, 83 WASH. U. L.Q. 1789, 1794-95 (2005); see also Angela Lipanovich, Comment, Smoke Before Oil: Modeling a Suit Against the Auto and Oil Industry on the Tobacco Tort Litigation Is Feasible, 35 GOLDEN GATE U. L. REV. 429, 432-33 (2005). 
A recent case filed by the State of California illustrates this potential form of litigation. ${ }^{34}$ In an action filed in federal district court against leading automobile manufacturers, the State alleges two causes of action for public nuisance: one under federal common law and the other under California state law. The complaint focuses on several key examples of damages. First, the State allegedly will be required to spend large sums of money on studies and infrastructure changes to its water systems: the Sierra Nevada snowpack, which is the source of much of California's water, has allegedly been shrinking. This decrease in snowpack is likely to increase flooding and interfere with the State's water system. ${ }^{35}$ Second, rising sea levels allegedly increase beach erosion and salt infiltration into the Sacramento BayDelta, which will require increased expenditures on levees. ${ }^{96}$ Third, climate change is allegedly causing more extreme heat events, increasing the risk of injury or death (especially to the elderly). ${ }^{37}$ Finally, the complaint alleges that

[d] ozens of other impacts have begun or are anticipated with a high level of certainty, including increased risk and intensity of wildfires, risk of prolonged heat waves, loss of moisture due to earlier snow pack melt and related impacts on forests and other ecosystems, and a change in ocean ecology as water warms.

The complaint adds that "[a]ll of these impacts are the subject of State study and planning, which costs the State millions of dollars." 39 Consequently, the State requests that the defendants be held jointly and severally liable for monetary damages. ${ }^{40}$

Claims of this kind face multiple barriers, including ill-defined law in the areas of public nuisance, proximate cause, preemption, and proof of damages. $^{41}$ Future claims are probably most likely to be filed

${ }^{34}$ Complaint, People ex rel. Lockyer v. Gen. Motors Corp., No. C06-05755 (N.D. Cal. Sept. 20, 2006).

35 Id. at 10-11.

${ }^{36}$ Id. at 11 .

Id. at 12.

${ }^{38} I d$.

${ }^{39}$ Id.

${ }^{40}$ Id. at 14. The state also requests declaratory relief and attorneys' fees. Id.

${ }^{41}$ For descriptions of these problems, see Grossman, supra note 23, at 23-27, 33-42; Oleszkiewicz \& Sanders, supra note 33 , at $940-42$. The issues that will arise in this litigation were explored in more depth by other participants in this Symposium. See, e.g., David T. Buente, Presentation, So You Want To Try a Climate Change Case?, at slides 7-10 (Nov. 16, 2006) (on file with author) (describing causation and proof of damages problems). 
by "[c]itizen property owners on islands and in coastal states, those that rely on snow pack or runoff for drinking water, and the states and municipalities that either own real property or are responsible for infrastructure repair and maintenance for their populations." lowing appraisal of the prospects for this litigation seems plausible:

Past litigation in U.S. courts against industries such as the tobacco industry and asbestos industry proceeded cautiously at first. Plaintiffs adapted to defense arguments, science caught up with the causation arguments and discovery often resulted in unfavorable documents being produced ....

Causation remains a big obstacle for potential plaintiffs to overcome in climate change litigation .... [P]laintiffs and their attorneys will draw on the same lessons discussed above to pursue claims and will reach a point where they can obtain significant discovery from defendants. Lawsuits do not have to be successful on the merits before they cause a defendant to spend significant time and resources. ${ }^{43}$

If nothing else, this litigation is likely to focus attention on compensation issues and uncover useful information; it may also increase political pressure for a nonlitigation solution.

\section{Potentially ANAlogous Compensation SCHEMES}

Climate change is an unprecedented global problem. Consequently, there is a vacuum of established rules and precedents dealing with this precise situation. It makes sense, then, to consider the possible lessons of compensation schemes designed for other kinds of widespread injuries. The compensation schemes I will consider involve a broad range of harmful events: terrorist acts, toxic torts, damage to natural resources, slavery and racial discrimination, natural disasters, and environmental damages caused by war. Clearly, none of these situations is an exact fit with climate change, but each provides some illuminating perspectives on the problems of designing a climate change compensation system.

\section{A. The 9/11 Fund and Similar Compensation Schemes}

In the aftermath of the terrorist attacks on September 11, 2001, Congress established a special victim's compensation fund. ${ }^{44} \mathrm{Com}$ -

${ }^{42}$ Oleszkiewicz \& Sanders, supra note 33, at 937.

43 Id. at 943 .

44 Air Transportation Safety and System Stabilization Act, Pub. L. No. 107-42, tit. iv, $\$ \S 401-409,115$ Stat. 230, 237-41 (2001) (codified as amended at 49 U.S.C. $\$ 40101$ 
pensation was limited to individuals who were present at one of the crash sites and who suffered "physical harm or death." covers economic loss, which is defined as including, among other things, medical expenses, loss of earnings, and "loss of business or employment opportunities . . . to the extent recovery for such loss is allowed under applicable State law"; it also covers noneconomic loss such as "physical and emotional pain." ${ }^{46}$ The law gives victims the alternative of going through the tort system, but tort recoveries against aircraft carriers are limited to the insurance coverage of the defendants. $^{47}$

A special master was appointed to administer the fund. The special master issued regulations to govern claims ${ }^{48}$ that in some instances seemed to go significantly beyond the statutory language. Although the statute called for an offset for life insurance and pension benefits, the special master reduced the offset to the extent of the individuals' policy payments or pension contributions. ${ }^{49}$ The special master also set an approximate $\$ 250,000$ floor on economic recoveries, and established a presumptive schedule covering economic loss, based on age, family size, and recent earnings, with a cap for the highest-level incomes. $^{50}$ Additionally, the special master created a schedule for noneconomic losses, with $\$ 250,000$ to each victim, and $\$ 100,000$ each to close relatives. ${ }^{51}$ Apparently, the special master's strategy was to "closely enough approximate the range of tort compensation to make no-fault benefits under the Fund an offer that could not be refused by most eligible parties." ${ }^{22}$ As it turned out, ninety-seven percent of the

(Supp. II 2002)). For an overview of the scheme, see Robert L. Rabin \& Suzanne A. Bratis, United States, in FinANCIAL COMPENSATION FOR Victims OF CATASTROPHES: A COMPARATIVE Lecal APPROACH 303, 335-41 (Michael Faure \& Ton Hartlief eds., 2006). For criticism of the $9 / 11$ compensation scheme, see Elizabeth Berkowitz, The Problematic Role of the Special Master: Undermining the Legilimacy of the September 11th Victim Compensation Fund, 24 YALE L. \& POL'Y REV. 1 (2006). The opt-out cases are now being considered in federal district court, along with claims for respiratory damages.

${ }^{45}$ Air Transportation Safety and System Stabilization Act, Pub. L. No. 107-42, $\$$ 405 (c) (1)-(c) (2) (A), 115 Stat. 239 (2001).

Id. $\$ 402(5),(7), 115$ Stat. 237.

${ }^{47}$ Id. $\$ 408(\mathrm{a}), 115$ Stat. 240.

428 C.F.R. $\$ 104$ (2006).

${ }^{49}$ Id. $\$ 104.47$.

so Id. $\$ 104.21(\mathrm{~b})(5), .41, .43, .45$.

${ }^{51}$ Id. $\$ 104.44, .46$.

52 Rabin \& Bratis, supra note 44 , at 341 . 
nearly 3000 surviving families applied to the fund, with only seventy families opting out. ${ }^{53}$

The 9/11 scheme is clearly distinguishable in important respects from the problems posed by climate change compensation. The September 11 terrorist attack was a discrete event that caused indisputable harm to affected individuals. People caught in the collapse of the twin towers died; those nearby may have experienced immediate injuries. Thus, screening claimants was not a major problem. Also, the $9 / 11$ compensation scheme may have had a partially patriotic motive.

Nevertheless, a couple of lessons may be drawn from the 9/11 fund. Clearly, the threat of tort liability pervaded the construction of $9 / 11$ compensation, and the potential for tort liability also will likely prompt climate change compensation in other forms. Also, the 9/11 fund illustrates the importance of providing standardized damage measures in the interests of efficient dispute resolution and fairness among victims. Moreover, the fund is a useful reminder, given the litigation orientation of American lawyers, that under some circum-

${ }^{53}$ Id. The Price-Anderson Act (also known as the Atomic Energy Damages Act), 42 U.S.C. $\S 2210(2000)$, is another example of a compensation scheme designed to limit tort litigation in order to protect a critical industry. The Act caps the total liability of the nuclear industry for damages resulting from a single nuclear accident, in return modifying normal tort rules to make it easier to establish liability. $\$ 2210$ (b). The purpose of the statute was to enable the nuclear industry to obtain insurance coverage. $\$ 2210(\mathrm{a})$. The Act also provides for assessments of the industry as a whole to cover additional victim compensation. $\$ 2210(\mathrm{~b})$. For further information about the Act, see U.S. DEP'T OF ENERGY, REPORT TO CONGRESS ON THE PRICE-ANDERSON ACT 4-9 (1999), available at http://www.gc.doe.gov/price-anderson/public-comments/ Nuclear\%20Energy\%20Agency/paa-rep.pdf.

A more recent compensation scheme presents a less happy picture. At the end of 2005, the Public Readiness and Emergency Preparedness Act (PREPA) was signed into law. Pub. L. No. 109-148, Div. C, 119 Stat. 2680, 2818-32 (2005) (codified at 42 U.S.C.A. $\$ \S 247 d-6 d, 247 d-6 e$ (Supp. 2006)). The statute provides immunity (for anything less than willful misconduct) for pharmaceutical manufacturers producing vaccines and other countermeasures for a biological emergency such as a bio-terror attack or pandemic flu outbreak. Id. $\$ 247 \mathrm{~d}-6 \mathrm{~d}$. The Secretary of the Department of Health and Human Services seems to have broad discretion in declaring such an emergency. $\S 247 d-6 d(b)$. Once an emergency is declared, a "Covered Countermeasure Process Fund" is established. $\S 247 \mathrm{~d}-6 \mathrm{e}(\mathrm{a})$. No appropriations will be provided until after the emergency is declared and the fund is established. $\$ 247 \mathrm{~d}-6 \mathrm{de}(\mathrm{b})$. Thus, there is no guarantee that funding will be forthcoming, which could leave victims in the position of having their tort remedies preempted, but without any alternative means of compensation. See Brian Kurt Copper II, "High and Dry?" The Public Readiness and Emergency Preparedness Act and Liability Protection for Pharmaceutical Manufacturers 24-28 (2006), available at http://papers.ssrn.com/sol3/papers.cfm?abstract_id=896299. 
stances, administrative compensation schemes may provide a more efficient and even fairer alternative.

\section{B. Environmental Damage and the United Nations Compensation Commission}

The United Nations Compensation Commission (UNCC) was established after the first Iraq war to handle claims against Iraq for warrelated damages. ${ }^{54}$ The United Nations Security Council held that Iraq "is liable under international law for any direct loss, damage, including environmental damage and the depletion of natural resources, or injury to foreign Governments, nationals and corporations, as a result of Iraq's unlawful invasion and occupation of Kuwait." ${ }^{55}$ According to the UNCC, compensable environmental claims include

(a) Abatement and prevention of environmental damage, including expenses directly relating to fighting oil fires and stemming the flow of oil in coastal and international waters;

(b) Reasonable measures already taken to clean and restore the environment or future measures which can be documented as reasonably necessary to clean and restore the environment;

(c) Reasonable monitoring and assessment of the environmental damage for the purposes of evaluating and abating the harm and restoring the environment;

(d) Reasonable monitoring of public health and performing medical screenings for the purpose of investigation and combating increased health risks as a result of the environmental damage; and

(e) Depletion of or damage to natural resources.

These provisions gave rise to intense disputes about compensation for damage to pure (nonmarketable) environmental resources and for interim damages to those resources prior to restoration. The UNCC ultimately held that these damages were compensable. ${ }^{57}$ One

${ }^{54}$ For information about the UNCC, see United Nations Compensation Commission, http://www2.unog.ch/uncc (last visited May 1, 2007).

${ }^{55}$ S.C. Res. 687, I 16, U.N. Doc. 5/RES/687 (Apr. 3, 1991).

${ }^{56}$ U.N. Comp. Comm'n [UNCC], Report and Recommendations Made by the Panel of Commissioners Concerning the First Installl]ment of "F4" Claims I 10, U.N. Doc. S/AC.26/2001/16 (June 22, 2001), available at http://www2.unog.ch/uncc/reports/ r01-16.pdf.

${ }^{57}$ Cymie Payne, UN Commission Awards Compensation for Environmental and Public Health Damage from 1990-91 Gulf War, INSIGHTS (Am. Soc'y Int'l Law), Aug. 10, 2005, I 7, http://www.asil.org/insights/2005/08/insights050810.html. 
method used to measure the value of resources was the cost of mitigation measures, such as providing alternative resources, which was used as a way to measure the loss of ecosystem services. ${ }^{58}$ The UNCC awarded approximately $\$ 5$ billion for 109 successful claims. ${ }^{59}$

There seems to be growing international recognition that "environmental damages will often extend beyond that which can be readily quantified in terms of clean-up costs or property devaluation." Thus, harm to "environmental values (biodiversity, amenity, etc.sometimes referred to as 'non-use values') is, as a matter of principle, no less real and compensable than damage to property, though it may be difficult to quantify."

Like the 9/11 fund, the UNCC dealt with the fallout from a discrete and readily identifiable human event. Nevertheless, the UNCC's resolution of claims gives us especially useful lessons for climate change compensation. The environmental impacts of the Gulf War were multitudinous and varied, presenting considerable difficulty for damage assessment. The UNCC's decisions are good precedent for extending compensation beyond harm done to marketable resources

${ }^{58}$ The application of this method of damage assessment is described in a recent overview of the UNCC's decisions:

Several claimants put a value on their temporary natural resource losses by proposing environmental projects designed to compensate for the loss of ecological services that the natural resources would have provided, had they not been damaged. Although the Panel viewed the proposed valuation methods using compensatory restoration projects as "relatively novel," it was willing to apply them "where there is sufficient evidence that primary restoration will not fully compensate for any identified losses." Accordingly, the Panel made awards that were quantified according to the cost of various compensatory projects: a cooperative rangeland management program to restore rangeland and wildlife habitat damaged by the influx of refugees into Jordan, and shoreline preserves in Kuwait and Saudi Arabia. In another case-Iran's claim for damage to rangelands from the presence of refugees-the Panel found it more appropriate to use the price of fodder to calculate an award rather than the value that Iran derived from lost ecological services.

Payne, supra note 57, I 8 (footnotes omitted) (quoting UNCC, Report and Recommendations made by the Panel of Commissioners Concerning the Fifth Instal[l]ment of "F4" Claims, U.N. Doc S/AC 26/2005/10 (2005)). For discussions of the concept of ecosystem services, see James Salzman, Creating Markets for Ecosystem Services: Notes from the Field, 80 N.Y.U. L. REV. 870, 871-75 (2005); James Salzman et al,, Protecting Ecosystem Services: Science, Economics, and Law, 20 STAN. ENVTL. L.J. 309, 309-13 (2001); James Salzman, Valuing Ecosystem Services, 24 ECOLOGY L.Q. 887, 890-92 (1997).

${ }^{59}$ Cymie R. Payne, Environmental Damage at the United Nations Compensation Commission 4 (unpublished manuscript, on file with author).

${ }^{60}$ U.N. Int'l Law Comm'n, Report of the International Law Commission on the Work of Its $53 d$ Session, U.N. Doc. A/56/10 (2001) (cmt. art. 36, at 252 I 16).

${ }^{61}$ Id. 
to include harm done to environmental amenities. The UNCC's approach to determining damages also may provide a workable model in the context of climate change. By focusing on the expense of mitigating the environmental harm, the UNCC has avoided difficult problems of identifying long-term environmental effects and valuing the resulting harms.

\section{U.S. Experience with Claims for Damages to Natural Resources}

The United States has considerable experience with compensation for harm to natural resources caused by incidents such as oil spills and other releases of hazardous substances. The primary mechanism for compensation in this context has been litigation by governmental bodies under state or federal statutes. Notably, culpability has played a secondary role at best.

Under U.S. law, compensation for nonmarket damages to environmental resources clearly exists. The default measure of damages is restoration cost. As the First Circuit has explained,

the appropriate primary standard for determining damages in a case such as this is the cost reasonably to be incurred by the sovereign or its designated agency to restore or rehabilitate the environment in the affected area to [its] pre-existing condition, or as close thereto as is feasible without grossly disproportionate expenditures. The focus in determining such a remedy should be on the steps a reasonable and prudent sovereign or agency would take to mitigate the harm done by the pollution, with attention to such factors as technical feasibility, harmful side effects, compatibility with or duplication of such regeneration as is naturally to be expected, and the extent to which efforts beyond a certain point would become either redundant or disproportionately expensive....

There may be circumstances where direct restoration of the affected area is either physically impossible or so disproportionately expensive that it would not be reasonable to undertake such a remedy. Some other measure of damages might be reasonable in such cases, at least where the process of natural regeneration will be too slow to ensure restoration within a reasonable period.... [O]ne possibility [is] "the reasonable cost of acquiring resources to offset the loss."

Oil spill litigation also provides some interesting statements about issues of proximate cause, which may well loom large in the climate

${ }^{62}$ Puerto Rico v. SS Zoe Colocotroni, 628 F.2d 652, 675-76 (1st Cir. 1980) (footnotes omitted) (quoting the 1977 amendments to the Clean Water Act, 33 U.S.C. $\$ 1321(\mathrm{f})(4)-(5))$. 
change context. In Benefiel $v$. Exxon Corp., the plaintiffs were consumers who alleged that the Exxon Valdez oil spill had resulted in higher oil prices. ${ }^{63}$ The flaw in their claim was the existence of intervening causes:

In this case, the spill itself did not directly cause any injury to the appellants. Rather, plaintiffs alleged the spill triggered a series of intervening events, including the decision of the United States Coast Guard to close the Port of Valdez to facilitate clean-up efforts; the alleged decision by refineries in the western United States to raise prices rather than to use their own oil reserves to make up any shortage; and the decision of wholesalers, distributors and retailers to pass on these price increases. ${ }^{64}$

The court concluded that the "plaintiffs themselves alleged the existence of at least one intervening act causing the price hike: the alleged decision of California oil refiners to exploit the supposed shortage." 65

Benefiel was only one piece of the massive litigation arising out of the Exxon Valdez spill. ${ }^{66}$ The district court held that some of these claims were foreclosed by the rule pronounced in Robins Dry Dock $\mathcal{E}^{2}$ Repair Co. $v$. Flint, which requires that a person must suffer "direct physical harm" in order to recover economic losses. ${ }^{67}$ On the other hand, there is a recognized exception to Robins for commercial fish-

${ }^{63} 959$ F.2d 805, 806 (9th Cir. 1992).

${ }^{64}$ Id. at 807.

${ }^{65}$ Id. at 808; see also Adkins v. Trans-Alaska Pipeline Liab. Fund, 101 F.3d 86, 89 (9th Cir. 1996) (applying the Benefiel test to the lost-profit claims of an electrical company, a cafe, tourist businesses, and boat repair companies).

${ }^{66}$ For an overview of the litigation, see Deborah S. Bardwick, Note, The American Tort System's Response to Environmental Disaster: The Exxon Valdez Oil Spill as a Case Study, 19 STAN. ENVTL. L.J. 259 (2000). The author concludes that despite the magnitude of the plaintiffs' recovery, it still was inadequate:

Based on the vast extent of litigation and multi-billion-dollar judgments awarded against Exxon, a casual observer might acquire an impression that the legal system fully compensated the losses suffered by those impacted by the spill. However, the legal system in fact denied redress to many plaintiffs who lost most of their livelihoods as a result of damage to natural resources. Many plaintiffs also did not receive compensation for non-market-based, intangible values that the resources had given them.

Id. at 262. Bardwick calls for "statutes that are specifically written to address the legitimate claims of individuals who suffer significant economic loss as an indirect consequence of the disaster, and create a right for native groups to recover for the actual full extent of their harm from loss of a subsistence lifestyle." Id. at 289.

${ }^{67}$ See In re Exxon Valdez, No. A89-0095-CV (HRH), 1994 WL 182856, at *1, *5 (D. Alaska Mar. 23, 1994) (citing Robins Dry Dock E Repair Co. v. Flint, 275 U.S. 303, 309 (1927)) (concluding that the Robins rule barred most claims for nonpecuniary damages). 
ermen. The district court held that this exception applied to fisheries that were actually closed to fishing by the spill, including claims that the market value of their subsequent salmon catch was decreased on the Japanese market because of concerns about contamination. ${ }^{68}$

Beyond the direct economic effects of the spill, Alaska natives also sought compensation for the disturbance caused to their way of life. The Ninth Circuit held that these damages were noncompensable:

Admittedly, the oil spill affected the communal life of Alaska Natives, but whatever injury they suffered (other than the harvest loss), though potentially different in degree than that suffered by other Alaskans, was not different in kind. We agree with the district court that the right to lead subsistence lifestyles is not limited to Alaska Natives. While the oil spill may have affected Alaska Natives more severely than other members of the public, the right to obtain and share wild food, enjoy uncontaminated nature, and cultivate traditional, cultural, spiritual, and psychological benefits in pristine natural surroundings is shared by all Alaskans. The Class [of Alaskan natives] therefore has failed to prove any "special injury" to support a public nuisance action. ${ }^{69}$

Much of current law concerning damages to natural resources involves a connection to hazardous waste liability. Pursuant to the Comprehensive Environmental Response, Compensation, and Liability Act of 1980 (CERCLA), ${ }^{70}$ responsible parties, such as waste site owners, operators, or waste transporters, can be liable for injury to, destruction of, or loss of natural resources resulting from releases of hazardous waste. ${ }^{71}$ The scope of this liability includes the reasonable cost of assessing such injury, destruction, or loss. ${ }^{72}$ Section 101(16) of CERCLA defines "natural resources" to mean

land, fish, wildlife, biota, air, water, ground water, drinking water supplies, and other such resources belonging to, managed by, held in trust by, appertaining to, or otherwise controlled by the United States (including the resources of the fishery conservation zone established by the

${ }^{68} I d$. at $* 6$. For a fuller discussion of the Robins rule, see Victor P. Goldberg, Recovery for Economic Loss Following the Exxon “Valdez” Oil Spill, 23 J. LEGAL STUD. 1 (1994).

${ }^{69}$ Alaska Native Class v. Exxon Corp., 104 F.3d 1196, 1198 (9th Cir. 1997) (citations and internal quotation marks omitted) (quoting RESTATEMENT (SECOND) OF TORTS $\$ 821 \mathrm{c}$, cmt. B (1977)).

${ }^{70}$ Pub. L. No. 96-510, 94 Stat. 2767, amended by Superfund Amendments and Reauthorization Act (SARA), Pub. L. No. 99-499, 100 Stat. 1613 (1986) (codified as amended at 42 U.S.C. $\$ \$ 9601-9675(2000)$ ).

7142 U.S.C. $\$ 9607$ (a) (2000).

${ }^{72} I d . \$ 9607(\mathrm{a})(4)(\mathrm{C})$. Note that the statutory scheme imposes strict liability; no proof of culpable mental state or negligence is needed to support a compensation claim. 
Magnuson-Stevens Fishery Conservation and Management Act), any State or local government, any foreign government, any Indian tribe, or, if such resources are subject to a trust restriction on alienation, any member of an Indian tribe.

Under section 107(f) of CERCLA, compensation for injury to natural resources is payable to the following entities: the U.S. government, any state for resources "within the State or belonging to, managed by, controlled by, or appertaining to such State," and any Indian tribe in specified situations. ${ }^{74}$ The statute creates no private cause of action for natural resource damage. Authority to sue is vested in the President-when suing on behalf of the United Statesor in the "authorized representative of any State," who "shall act on behalf of the public as trustee of such natural resources." ${ }^{, 75}$ Sums recovered must be retained by the trustee "for use only to restore, replace, or acquire the equivalent of" the natural resources injured, destroyed, or lost. ${ }^{76}$

CERCLA provides compensation for injury to an important but limited category of natural resources. Section 101(16) speaks of resources "belonging to, managed by, held in trust by, appertaining to, or otherwise controlled by" the government. ${ }^{77}$ This language seems to encompass not only resources owned by a government, but also those subject to the "public trust," such as navigable waters, wetlands, and parklands. Less clear is whether the language also includes resources that are regulated by a government for purposes of environmental protection-such as endangered species, coastal zones, aquifers providing public water supplies, and the ambient air-or that could be regulated constitutionally. ${ }^{78}$

How are the recoverable damages to be measured? Section 301 (c) of CERCLA directs the President to promulgate regulations for

7342 U.S.C. $\$ 9601$ (16) (citation omitted).

${ }^{74} \mathrm{Id} . \S 9607(\mathrm{f})$.

${ }^{75} \mathrm{Id}$.

${ }^{76} I d$.

${ }^{77} I d . \$ 9601(16)$.

${ }^{78}$ See Barry Breen, CERCLA's Natural Resource Damage Provisions: What Do We Know So Far?, 14 ENVTL. L. REP. 10,304, 10,305-06 (1984) (discussing the "nexus requirement" of CERCLA's "natural resources" definition). Another possible analogy for climate change compensation might be liability for cleanup of hazardous waste, which is covered elsewhere in CERCLA. See, e.g., 42 U.S.C. $\$ 9621$ (providing cleanup standards for "hazardous substances, pollutants, and contaminants"). 
"the assessment of damages for injury to, destruction of, or loss of" natural resources. ${ }^{79}$ These regulations shall specify:

(A) standard procedures for simplified assessments requiring minimal field observation, including establishing measures of damages based on units of discharge or release or units of affected area, and (B) alternative protocols for conducting assessments in individual cases to determine the type and extent of short- and long-term injury, destruction, or loss. Such regulations shall identify the best available procedures to determine such damages, including both direct and indirect injury, destruction, or loss and shall take into consideration factors including, but not limited to, replacement value, use value, and ability of the ecosystem or resource to recover. ${ }^{80}$

The "standard procedures" are referred to as "Type A" rules, and the "alternative protocols" as "Type B" rules.

The President assigned responsibility for promulgating the regulations to the Department of the Interior (DOI). In 1986, the DOI belatedly published final regulations containing both Type A and Type $B$ assessment rules. ${ }^{81}$ Both sets of rules were challenged in court by state governments, environmental organizations, and industry groups. ${ }^{82}$ Major portions of the Type B rules were found to violate CERCLA in Ohio v. Department of the Interior." According to the court, the "most significant issue" in the Ohio case concerned the validity of a provision stating that damages should be "the lesser of: restoration or replacement costs; or diminution of use values." ${ }^{84}$ The DOI rules defined "use value" as

the value to the public of recreational or other public uses of the resource, as measured by changes in consumer surplus, any fees or other payments collectable by the government or Indian tribe for a private

${ }^{79} 42$ U.S.C. $\$ 9651$ (c) (1).

${ }^{80}$ Id. $\$ 9651(\mathrm{c})(2)$.

${ }^{81}$ The Type A and Type B regulations have been codified at 43 C.F.R. pt. 11, under the title of Natural Resource Damage Assessment Regulations.

${ }^{82}$ Type A rules for coastal and marine environments were upheld in part and vacated in part in Colorado v. Department of Interior, 880 F.2d 481, 483 (D.C. Cir. 1989). In 1996, the Department promulgated further Type A rules for coastal and marine environments and Great Lakes environments. National Resource Damage AssessmentsType A Procedures, 61 Fed. Reg. 20,560 (1996) (codified at 43 C.F.R. pt. 11 (1997)). The court upheld these Type A procedures in National Ass'n of Manufacturers $v$. Department of Interior, 134 F.3d 1095, 1099 (D.C. Cir. 1998).

880 F.2d 432, 438 (D.C. Cir. 1989) (upholding in part and invalidating in part the DOI's Type B rules). This case was decided the same day as Colorado v. Department of Interior.

${ }^{84} I d$. at 441 (quoting 43 C.F.R. $\$ 11.35(\mathrm{~b})(2)$ (1987)). 
party's use of the natural resource, and any economic rent accruing to a private party because the government or Indian tribe does not charge a fee or price for the use of the resource.

The state and environmental challengers in Ohio argued that CERCLA requires damages to be at least sufficient to pay the cost in every case of restoring, replacing, or acquiring the equivalent of the damaged resource. Because, in many cases, lost use values will be lower than the cost of restoration or replacement, the DOI's rule would result in damage awards too small to pay for restoration. The court used an example-which may have been inspired by the thenrecent Exxon Valdez oil spill in Alaska-to illustrate the "enormous practical significance" of the "lesser of" rule:

[I] magine a hazardous substance spill that kills a rookery of fur seals and destroys a habitat for seabirds at a sealife reserve. The lost use value of the seals and seabird habitat would be measured by the market value of the fur seals' pelts (which would be approximately $\$ 15$ each) plus the selling price per acre of land comparable in value to that on which the spoiled bird habitat was located. Even if, as likely, that use value turns out to be far less than the cost of restoring the rookery and seabird habitat, it would nonetheless be the only measure of damages eligible for the presumption of recoverability under the Interior rule.

The court held that, under CERCLA, the DOI was not entitled to treat use value and restoration cost as having "equal presumptive legitimacy" as a measure of damages to natural resources. ${ }^{87}$ Primary among the statutory provisions cited by the court was section 107 (f) (1), which states that natural resource damages recovered by a government trustee are "for use only to restore, replace, or acquire the equivalent of such natural resources," and that the measure of damages "shall not be limited by the sums which can be used to restore or replace such resources." ${ }^{88}$ The court concluded that Congress intended "to establish a distinct preference for restoration costs as the measure of damages." ${ }^{89}$

The DOI sought to justify its "lesser of" rule as being economically efficient. The court replied as follows:

\footnotetext{
${ }^{85}$ Id. at 475 (quoting 43 C.F.R. $\$ 11.83$ (b) (1) (1988)).

${ }^{86}$ Id. at 442 (footnotes omitted).

${ }^{87}$ Id. at 444 .

${ }^{88}$ Id. (quoting 42 U.S.C. $\S 9607$ (f) (1) (2000)).

${ }^{89}$ Id.
} 
Under DOI's economic efficiency view, making restoration cost the measure of damages would be a waste of money whenever restoration would cost more than the use value of the resource. . . .

... Congress' refusal to view use value and restoration cost as having equal presumptive legitimacy merely recognizes that natural resources have value that is not readily measured by traditional means. Congress delegated to Interior the job of deciding at what point the presumption of restoration falls away, but its repeated emphasis on the primacy of restoration rejected the underlying premise of Interior's rule, which is that restoration is wasteful if its cost exceeds-by even the slightest amountthe diminution in use value of the injured resource. ${ }^{90}$

With respect to the determination of "use value," the DOI regulations have prescribed methods to be employed when the damaged natural resources are not traded in the market. One of these methods is known as contingent valuation, or CV. Some parties in the Ohio case challenged DOI's acceptance of contingent valuation in the regulations. The court rejected the challenge, saying in part:

The CV process "includes all techniques that set up hypothetical markets to elicit an individual's economic valuation of a natural resource." CV involves a series of interviews with individuals for the purpose of ascertaining the values they respectively attach to particular changes in particular resources....

It cannot be gainsaid that DOI's decision to adopt CV was made intelligently and cautiously. DOI scrutinized a vast array of position papers and discussions addressing the use of CV. It recognized and acknowledged that CV needs to be "properly structured and professionally applied." It eliminated a feature of $\mathrm{CV}$, as originally proposed, that might have resulted in overly high assessments. We find DOI's promulgation of CV methodology reasonable and consistent with congressional intent, and therefore worthy of deference. ${ }^{91}$

In 1994, the DOI promulgated new regulations on natural resource damage assessments in response to the Ohio decision. ${ }^{92}$ These regulations allow "trustee officials to recover the costs of restoration, rehabilitation, replacement, and/or acquisition of equivalent resources in all cases."

${ }^{90}$ Id. at 456-57 (footnotes omitted).

${ }^{91}$ Id. at 475-77 (quoting Natural Resource Damage Assessments, Final Rule, 51 Fed. Reg. 27,720, 27,721 (1986) (codified at 43 C.F.R. $\$ 11.83$ (d) (5) (i) (1988))) (footnotes omitted).

${ }^{92}$ Natural Resource Damage Assessments, Final Rule, 59 Fed. Reg. 14,262 (Mar. 25, 1994) (codified at 43 C.F.R. $\$ \S 11.10-11.93$ (2004)).

${ }^{93} I d$. at 14,264 (codified at 43 C.F.R. $\$ 11.15$ (2004)). The 1994 regulations were upheld in almost all respects in Kennecott Utah Copper Corp. v. Department of Interior, 88 
The CERCLA regulations are echoed by a separate legal scheme relating to oil spills. The Oil Pollution Act of 1990 provides that the measure of natural resource damages is “(A) the cost of restoring, rehabilitating, replacing, or acquiring the equivalent of, the damaged natural resources; $(B)$ the diminution in value of those natural resources pending restoration; plus (C) the reasonable cost of assessing those damages." ${ }^{94}$

These costs are to be assessed with respect to restoration plans, which are to be promulgated by federal or state trustees. ${ }^{95}$ Double recoveries are precluded. $^{96}$ The President must issue damage assessment regulations, and, pursuant to those regulations, a rebuttable presumption of correctness applies to damage determinations. ${ }^{97}$

One of the components of damages described above is the cost of restoration. Arguably, only restoration can fully compensate the public for loss of a natural area. ${ }^{98}$ Unfortunately, one of the lessons of the Exxon Valdez oil spill is that our technological capabilities in the area of restoration are still quite primitive, and may, in fact, be counterproductive. $^{99}$ Paralleling the CERCLA regulations for natural resource damages, the National Oceanic and Atmospheric Administration (NOAA) developed equivalent rules under the Oil Pollution Act of $1990 .{ }^{100}$

F.3d 1191, 1231 (D.C. Cir. 1996). For further discussion of the valuation of natural resource damages, see Christine M. Augustyniak, Economic Valuation of Services Provided by Natural Resources: Putting a Price on the "Priceless", 45 BAYLOR L. REV. 389, 392-403 (1993); Daniel S. Levy \& David Friedman, The Revenge of the Redwoods? Reconsidering Property Rights and the Economic Allocation of Natural Resources, 61 U. CHI. L. REV. 493, 497-515 (1994). For more on the contingent valuation method, see Ronald G. Cummings \& Glenn W. Harrison, Was the Ohio Count Well Informed in Its Assessment of the Accuracy of the Contingent Valuation Method?, 34 NAT. RESOURCES J. 1 (1994).

9433 U.S.C. $\$ 2706$ (d) (1) (2000).

${ }^{95}$ Id. $\$ 2706(\mathrm{c})(1)-(2)$.

96 Id. $\S 2706(\mathrm{~d})(3)$.

${ }^{97}$ Id. $\$ 2706(\mathrm{e})$.

${ }^{98}$ See Heidi Wendel, Note, Restoration as the Economically Efficient Remedy for Damage to Publicly Owned Natural Resources, 91 Colum. L. REv. 430, 430 (1991).

99 See Marguerite Holloway, Trends in Environmenlal Technology: Soiled Shores, SCI. AM., Oct. 1991, at 102, 103 (noting that the oil spill "tore off the veil of preparedness worn by U.S. industry and by federal and local governments. Technology proved unable to contain or contend with the spill, and it is likely to prove inadequate again").

${ }^{100} 15$ C.F.R. $\$ 990$ (2006). These rules were largely upheld in General Electric Co. $v$. Department of Commerce, 128 F.3d 767, 769 (D.C. Cir. 1997). The court found the Ohio ruling decisive regarding the general legitimacy of contingent valuation. Any claims that a particular contingent valuation was performed without adequate safeguards could be addressed in a later enforcement proceeding. Id. at 773-74. 
These compensation schemes for natural resources provide some valuable lessons. Compensation should not be limited to losses that may be measured in markets. Rather, the cost of restoring natural resources (or providing substitutes) is a plausible default measure. Where restoration or substitution becomes impossible, contingent valuation may operate as an alternative measure of damages. Direct economic losses are also compensable, but not more remote economic harms such as higher prices to consumers. By allowing the use of contingent valuation as a method for measuring harm, the approach to compensation for environmental damage from toxic substances and petrochemicals goes well beyond what I propose with respect to harm resulting from climate change.

\section{Compensation for Natural Disasters}

Steps can be taken to limit the human impact of natural disasters. Nevertheless, harm to human life and property cannot be avoided completely. This raises the question of compensation. The legal system provides a mix of several public and private sector methods for compensating victims of natural disasters. Each of the methods that has been used to provide compensation has its limitations.

The first method of compensation is private insurance. However, the unavailability of insurance for catastrophic risks-due to expense or underwriting risks, the exclusion of catastrophic risks by contract from insurance policies, and the difficulty of handling very large numbers of claims-creates significant hurdles to privately insuring against losses caused by natural disasters. The second method of compensation, litigation against responsible private parties, also has its limitations. These include the need for proof of negligence or another basis for liability, limits on the financial assets and insurance coverage of potential defendants, and other judicial doctrines limiting recovery. Third, compensation might be obtained from the government through various routes: tort claims against federal or state governments for negligence (subject to immunity defenses), claims under special compensation schemes established for particular disasters, and claims based on constitutional provisions requiring compensation for the taking (or in some states, damaging) of property. As two astute observers of the compensation system explain:

In the final analysis, the U.S. has what might well be termed a patchwork system for providing financial compensation for catastrophic loss: partly tort, partly public social welfare benefit programs, and partly private insurance coverage (often mandated); in some instances federally-initiated 
and in some instances at the behest of state government. Inevitably, in such a multifaceted milieu, where the tendency has been to develop discrete schemes in response to particularized categories of disasters (or rely on general welfare schemes that were enacted without disaster relief in mind), there will be ongoing fine-tuning of the system and a continuing dialogue over the efficacy of the measures in place. While the description of the U.S. system may not point to a single best model for delivering financial compensation for catastrophic harm in all circumstances, its very complexity indicates the variety of pathways that might be taken. ${ }^{10}$

With respect to compensation for one type of natural disasterflooding-governments play an important role. Although the federal government generally has no legal liability for failure of the flood control system even for negligence, it has often found itself in the position of bailing out flood victims with various forms of disaster relief. The flood insurance program is intended both to regularize this practice and to provide incentives to municipalities and individuals to limit their risk of exposure. The basics of flood insurance have been succinctly summarized by the Congressional Research Service:

In 1968, Congress created the NFIP [National Flood Insurance Program] in response to the trend of development and redevelopment in flood-prone areas, the increasing damages caused by floods, and rising cost of taxpayer funded disaster relief for flood victims. Today, the NFIP is among the nation's largest domestic liabilities, along with the Social Security System and federal health programs such as medicare and medicaid.... Federal flood insurance is currently offered to homeowner[s], renters, and business owners in over 20,000 participating communities that adopt and enforce floodplain management regulations which conform to NFIP standards.

...

The NFIP serves two major functions: underwriting flood insurance and leading floodplain management. Various entities have specific roles to play under the NFIP. The federal government assumes all liability for the insurance coverage, sets the rates, coverage limitations, and eligibility requirements, designates special flood hazard areas (SFHA) with the issuance of flood insurance rate maps (FIRMs) and provides grant funding for mitigation planning activities.... Finally local communities with jurisdiction over land use adopt, administer, and enforce floodplain development regulations.

The NFIP does not operate on the traditional insurance definition of fiscal solvency; rather, it operates under a statutory mandate that premiums on pre-FIRM structures-i.e., structures built before the issuance of 
a FIRM or before 1975, whichever is later-must be reasonable and, if necessary, be subsidized. ${ }^{102}$

Flood insurance presents a tricky set of problems. ${ }^{103}$ If it is priced too high, people simply fail to insure. If it is priced too low, society in effect subsidizes individuals to build in high-risk areas. Obviously, the solution is to price it "just right"-but finding the right price may not be easy, especially since there is no private market to use as a benchmark.

Private insurance also presents distinctive issues. ${ }^{104}$ The insurance industry seems reluctant to provide coverage for large-scale natural disasters. This reluctance may be in part because of the difficulty of assessing future risks, or because of the underwriting costs associated with maintaining large levels of reserve or reinsurance-not to mention competition from various government-subsidized schemes. In the aftermath of Hurricane Andrew, Florida established a backup fund for individuals who could not get private coverage, funded by assessments of insurers. (This bears some resemblance to the more familiar "designated risk" pool for car insurance.) The number of policy holders dropped by over ninety percent in just a few years, but the remaining coverage still represented over $\$ 10$ billion in exposure. Florida also offers reinsurance to private insurers at subsidized rates. ${ }^{105}$

Natural disaster compensation provides several key lessons for climate change. Private insurance may be inadequate to deal with large-scale impacts as opposed to more localized harms. Also, given the variety of institutional forms for providing compensation, we should not focus exclusively on the litigation system as a basis for compensation. Because of the important role that insurance could play, the compensation system should focus on those harms that are not easily insurable (because they are too large, predictable, or widespread).

${ }^{102}$ Cong. Research Serv., Federal FloOd Insurance: The Repetitive loss PROBLEM 6-7 (June 30, 2005).

${ }^{103}$ For fuller discussion of issues relating to flood insurance, see DANIEL A. FARBER \& JIM CHEN, DiSASTERS AND THE LAW: KATRINA AND BEYOND 178-85 (2006).

${ }^{104}$ For more in-depth coverage of issues relating to private insurance, see id. at 185-92; PAMng the Price: The Status and Role OF InSURANCE AGainst Natural DISASTERS IN THE UNITED STATES (Howard Kunreuther \& Richard J. Roth, Sr. eds., 1998); Howard Kunreuther, Has the Time Come for Comprehensive Natural Disaster Insurance?, in ON RISK AND DISASTER: LESSONS FROM HURRICANE KATRINA 175, 177-83, 19098 (Ronald J. Daniels et al. eds., 2006).

${ }^{105}$ For further discussion of the Florida programs, see Rabin \& Bratis, supra note 41 , at $345-47$. 


\section{E. Reparations for Slavery and Racial Discrimination}

A very different setting for compensation involves claims for reparations by the descendants of American slaves. The reparations issue has given rise to vigorous scholarly debate. ${ }^{106}$ Some of the debate concerns the application of private law theories of liability in this setting. More attention, however, has been given to broader policy issues, which are hotly disputed. The argument for reparations is at heart a simple one. We recognize today that slavery was one of the great crimes of history, followed by a long and shameful legacy of legalized discrimination. These wrongs have never been fully acknowledgednot even in the form of an explicit apology-nor has recompense been made. ${ }^{107}$ Opponents of reparations do not question the injustice of slavery and Jim Crow laws. They do question whether reparations would represent a sensible response. They see reparations as deeply divisive, increasing rather than healing racial divisions. Opponents also fear that the quest for reparations will discourage African Americans from assuming responsibility for their own futures. Finally, critics raise a host of questions about how to calculate the damages for this past misconduct and how to distribute those damages to current generations of African Americans. ${ }^{108}$

Reparations have not yet gained widespread support (which may not be a promising sign for climate change compensation). As Saul Levmore puts it, black reparations may be "as unlikely to materialize ... as a renegotiation with current American Indians regarding the purchase of Manhattan Island long ago or as a recovery from present Southerners for the firing on Fort Sumter." 109 Indeed, public opinion

${ }^{106}$ For a sampling of viewpoints, see Alfred L. Brophy, The Cultural War over Reparations for Slavery, 53 DEPAUL L. REV. 1181 (2004); Hanoch Dagan et al., Introduction, Symposium, The Jurisprudence of Slavery Reparations, 84 B.U. L. REV. 1135 (2004); Richard A. Epstein, The Case Against Black Reparations, 84 B.U. L. REV. 1177 (2004); Calvin Massey, Some Thoughts on the Law and Politics of Reparations for Slavery, 24 B.C. THIRD WORLD L.J. 157 (2004); Michelle E. Lyons, Note, World Conference Against Racism: New Avenues for Slavery Reparations?, 35 VAND. J. TRANSNAT'L L. 1235 (2002).

${ }^{107}$ Some of the key arguments for reparations are made in ROY L. BROOKS, ATONEMENT AND FORGIVENESS: A NEW MODEL FOR BLACK REPARATIONS 119-63 (2004); Anthony E. Cook, King and the Beloved Community: A Communitarian Defense of Black Reparations, 68 GEO. WASH. L. REV. 959, 980-1012 (2000); Charles J. Ogletree, Jr., Repairing the Past: New Efforts in the Reparations Debate in America, 38 HARV. C.R.-C.L. L. REV. 279, 28285 (2003).

${ }_{108}$ These objections are discussed in Brophy, supra note 106, at 1201-03; Epstein, supra note 106, at 1191-92; and Massey, supra note 106, at 168.

${ }^{109}$ Saul Levmore, Privatizing Reparations, 84 B.U. L. REV. 1291, 1292 (2004). 
polls show that only four percent of whites would support payment of compensation for slavery (as opposed to the two-thirds of blacks who would support such payments).

Nevertheless, there are some precedents for reparations. Florida paid survivors of the 1923 Rosewood Massacre $\$ 150,000$ each and made substantial payments to the descendants of other victims. ${ }^{111}$ The United States paid roughly $\$ 800$ million to Native Americans for wrongfully seized land as early as 1946 , and, in 1998 , it paid $\$ 1.65$ billion to Japanese Americans wrongfully interned during World War II. ${ }^{112}$ The federal government also paid $\$ 9$ million to African Americans who were denied treatment for syphilis as part of the infamous Tuskegee experiments. ${ }^{113}$ In another gesture of political support, California passed a statute requiring insurance companies to submit records of slaveholder insurance policies to a central registry. ${ }^{114}$ More recently, J.P. Morgan Chase apologized for the actions of its predecessors in accepting slaves as collateral (and taking possession in some cases); the apology was accompanied by a $\$ 5$ million pledge for black college students from Louisiana. ${ }^{115}$ Finally, in a notable recent opinion, Judge Posner held that the majority of the plaintiffs, who were African American slave descendants requesting damages from companies that had participated in slavery, lacked standing or were barred by the statute of limitations-but some claims, primarily those brought by "legal representatives" and those asserting consumer protection violations, did survive dismissal. ${ }^{116}$ Thus, at least a glimmer of hope may exist for public support of some kind of reparations program. $^{117}$

Some of the resistance to reparations might be muted through creative benefit systems. Dean Levmore proposes a privatized repara-

${ }^{110}$ Brophy, supra note 106, at 1184 tbl.2.

II' Lyons, supra note 106, at 1243 (noting they payment of compensation to African-Americans whose community "was burned to the ground by whites in 1923").

${ }^{112}$ Levmore, supra note 109 , at 1303 n.50.

113 Id.

114 Lyons, supra note 106, at 1264.

${ }^{115}$ Ashley M. Heher, Slave Descendants Attempt To Revive Reparations Suit, MSNBC.COM, Sept. 27, 2006, available at http://www.msnbc.msn.com/id/15037694.

${ }^{116}$ In $r e$ African-American Slave Descendants Litig., 471 F.3d 754, 759-63 (7th Cir. 2006).

117 Charles Ogletree also cites municipal, state, and federal legislation addressing reparations. Ogletree, supra note 107, at 280-81. Moreover, as he points out, Congress waived the statute of limitations in a suit involving discrimination by the Department of Agriculture against black farmers in the South. Id. at 303. 
tions scheme that might avoid some of the political objections. The scheme involves incentives for private financing-up to $\$ 10$ billionfor programs to compensate black World War II veterans for wartime discrimination and to encourage high school graduation. ${ }^{118}$ We might imagine a similar scheme to encourage support for individuals who have had to relocate after their previous homes have become uninhabitable or risky due to climate change.

In some of the recent debate over reparations, there seems to have been a shift in the rationale for reparation and the types of reparation sought by advocates. Some of the key goals are informational and symbolic: to admit past wrongs and advance public understanding. In terms of actual compensation, the interest seems to be community centered rather than individualized, such that it becomes possible to think of affirmative action programs as a form of reparation. Also, some advocates place greater emphasis on social welfare than on the prevention of unjust enrichment or redress for injuries. ${ }^{119}$

One of the lessons of the reparations debate is that the passage of time makes compensation increasingly difficult. Moral responsibility becomes diffused, and damages become progressively more difficult to trace. Similarly, GHG emissions today may have harmful effects over many decades, but delaying compensation in the meantime would be a mistake: compensation denied at any time is very likely to be compensation denied forever. Thus, the compensation scheme should prefer ex ante measures of damages rather than waiting for harm to occur.

Another lesson of the reparations debate is that "compensation" can serve a number of functions in addition to payments that redress identifiable injury. By focusing attention on the moral responsibility of certain actors for the plight of other actors, it may also provide a way of fostering socially beneficial programs. Thus, even if we do not adopt an explicit compensation system, trying to assign responsibility for harm to particular actors may be a useful exercise. Also, we should consider a variety of methods for delivering compensation, not just cash payments.

118 Levmore, supra note 109, at 1300-01.

119 See, e.g., Alfred L. Brophy, Reconsidering Reparations, 81 IND. L.J. 811, 814 (2006) (proposing "an alternative vision of the moral basis of reparations claims" that focuses on legislative action rather than litigation). 


\section{F. Toxic Torts}

A fairly natural analogy to climate change liability involves litigation over harm caused by exposure to toxic substances. This litigation has been pursued vigorously, though with varied success. In some ways, the failures are as instructive as the successes, in terms of identifying the knotty issues that a compensation system should try to avoid as much as possible.

In considering compensation for individuals exposed to toxic substances, we can begin by distinguishing between ex ante and ex post compensation. Ex ante compensation provides redress for the existence of the risk before the risk has caused actual harm; ex post compensation provides for redress after injury has occurred. In the climate change setting, ex ante compensation would involve, for example, the cost of constructing flood defenses. Ex post compensation would be assessed after the floods had actually occurred.

\section{Claims for Ex Ante Compensation}

Ex ante claims for toxic torts come in several guises. First, the plaintiff may have an existing physical injury but be faced with the threat that the condition may worsen. Second, the plaintiff may have no existing injury or disease but may suffer an increased risk of developing a particular disease, such as cancer, in the future. The prevailing rule for cases in these two categories is that increased risk of developing a future disease is not compensable unless the plaintiff can establish that the probability of the future disease is greater than fifty percent. ${ }^{120}$ Third, because of the plaintiff's susceptibility to disease, she may suffer present emotional distress, which may or may not be accompanied by physical manifestations. This category is not very relevant for present purposes; it seems unlikely that compensation will be provided for the mental distress of contemplating future harms caused by climate change. Finally, the plaintiff facing an enhanced risk of future serious illness may incur present and future medical expenses for surveillance of the possible development of the disease.

${ }^{120}$ This rule has, however, met some criticism. See, e.g., Lisa Heinzerling \& Cameron Powers Hoffman, Tortious Toxics, 26 WM. \& MARY ENVTL. L. \& POL'Y REV. 67, 73 (2001) (explaining this probability rule and arguing that it "has hugely arbitrary and inequitable results"). For example, in Jackson v. Johns-Manville Sales Corp., 781 F.2d 394, 396, 413 (5th Cir. 1986) (en banc), the court upheld damages for fear of cancer where the plaintiff already had asbestosis and had a greater than fifty percent likelihood of developing cancer. 
This fourth category has received particular attention from the courts and is also especially relevant for our purposes.

The prevailing approach to medical monitoring is illustrated by In re Paoli Railroad Yard PCB Litigation. ${ }^{121}$ The Third Circuit held that a medical monitoring claimant must prove four elements:

1. Plaintiff was significantly exposed to a proven hazardous substance through the negligent actions of the defendant.

2. As a proximate result of exposure, plaintiff suffers a significantly increased risk of contracting a serious latent disease.

3. That increased risk makes periodic diagnostic medical examinations reasonably necessary.

4. Monitoring and testing procedures exist which make the early detection and treatment of the disease possible and beneficial. ${ }^{12}$

In most medical monitoring cases, "litigants pursued or courts awarded the traditional common-law lump sum of monetary damages." ${ }^{123}$ In a few toxic exposure cases, however, litigants have requested, or courts have expressed their preference, that the defendant "pay the expenses [of medical surveillance] on a periodic basis out of a court-supervised trust fund or similar mechanism." ${ }^{24}$ Medical monitoring thus seems to be a form of ex ante compensation, since it is based on precautionary actions rather than on an assessment of actual physical harm.

\section{Claims for Ex Post Compensation}

The largest damages result from claims of death or serious illness as a result of exposure to toxic substances. These damage claims are also among the hardest to prove. One of the most serious sets of problems relates to proof of causation. It may be difficult to establish

${ }^{121} 916$ F.2d 829 (3d Cir. 1990).

129 . at 852 .

${ }^{123}$ Amy B. Blumenberg, Note, Medical Monitoring Funds: The Periodic Payment of Future Medical Surveillance Expenses in Toxic Exposure Litigation, 43 HASTINGS L.J. 661, 665 (1992) (footnotes omitted).

${ }^{124} I d$. at 666. The leading case on medical surveillance is Ayers $v$. Township of Jackson, 525 A.2d 287, 312 (N.J. 1987), which held that "the cost of medical surveillance is a compensable item of damages... where such surveillance to monitor the effect of exposure to toxic chemicals is reasonable and necessary." For a case rejecting a cause of action for medical monitoring, see Hinton ex rel. Hinton $v$. Monsanto Co., 813 So. 2d 827, 828 (Ala. 2001), which held that Alabama law does not recognize a "distinct cause of action for medical monitoring in the absence of a manifest physical injury or illness." 
that a toxic substance is even capable of causing a specific disease, let alone that it actually caused that disease in one particular plaintiff. This question of general causation often involves difficult and only partially resolved scientific questions. ${ }^{125}$

Even when a general link between a disease and exposure to a substance has been established, it may be difficult to show that a particular individual's disease was caused by exposure to that specific substance:

Epidemiological studies may establish that a substance can cause the type of harm suffered by a plaintiff, satisfying general causation. But a plaintiff must still demonstrate that the particular harm was in fact the result of exposure to a given substance. Epidemiological studies, however, can only attribute a proportion of the incidence of disease in a population to any particular source. They are not designed to prove specific causation. Specific causation requires a plaintiff to prove by a preponderance of the evidence that the defendant caused that particular plaintiff's harm. Many courts interpret the preponderance standard to require a relative risk ratio of 2.0 or greater-for example, a defendant's conduct more than doubled the plaintiff's risk of injury.... Thus, if an epidemiological study indicates that exposure to a particular substance increases the incidence of a disease among those exposed by only forty percent, then a court will probably find that the plaintiff has failed to meet the burden of proving specific causation unless more direct evidence is offered. ${ }^{126}$

There is considerable scholarly support for a different approach to probabilistic harm. Rather than providing full compensation for victims who have proven at least a fifty percent probability of causation and none for those who have not met that burden of proof, the new approach would provide proportional recovery to all victims. ${ }^{127}$ Thus,

\footnotetext{
${ }^{125}$ For a discussion of these issues in the context of risk assessment, see DANIEL $A$. FARBER ET AL., CASES AND MATERIALS ON ENVIRONMENTAL LAW 68-81 (7th ed. 2006).

${ }^{126}$ Albert C. Lin, Beyond Tort: Compensating Victims of Environmental Toxic Injury, 78 S. CAL. L. REV. 1439, 1449-50 (2005) (footnotes omitted). For further discussion of this issue, see Restatement (THIRD) OF TORTS: LIAB. FOR PHYSICAL HARM $\$ 28 \mathrm{cmt}$. b (Proposed Final Draft No. 1 2005) (discussing "[r] easonable inference and speculation in proving causation"); id. $\$ 28 \mathrm{cmt}$. c (discussing "[t]oxic substances and disease"); id. $\$ 28 \mathrm{~cm}$ ts. a-c reporters' note.

${ }^{127}$ See, e.g., Richard Delgado, Beyond Sindell: Relaxation of Cause-in-Fact Rules for Indeterminate Plaintiffs, 70 CAL. L. REV. 881, 883 (1982) (exploring a "reverse-Sindell' doctrine," in which "uncertainty lies not in the defendant class, but in the plaintiff class"); William M. Landes \& Richard A. Posner, Tort Law as a Regulatory Regime for Catastrophic Personal Injuries, 13 J. LEGAL STUD. 417, 418 (1984) (arguing in favor of a system in which "the injury on which the victim of a catastrophic accident can base a tort suit is defined . . . as the impact or exposure that planted the seeds of the illness"); David Rosenberg, The Causal Connection in Mass Exposure Cases: A "Public Law" Vision of
} 
if there is, for example, a sixty percent chance that a victim's injury was caused by exposure to the toxic chemical, the victim would receive compensation for sixty percent of her loss. Similarly, if the probability is only twenty percent, twenty percent of the loss would be compensable.

When there are classes of potential victims with varying degrees of risk, there is a strong theoretical argument for departing from proportionality. Rather, the optimal form of compensation in such cases may be to assess the defendant with the full expected harm caused by its actions, but to distribute the damages only to the most likely victims. ${ }^{128}$ In this scheme, the classes with the highest risk level receive full compensation, starting at the top with the class most at risk; the court then proceeds down the list, awarding compensation until the defendant has paid the full expected value of the harm. This method maximizes the probability that the funds will go to redress injuries that were actually caused by the defendant, and it correspondingly minimizes the error cost that the funds will go to individuals whose harm was not in fact caused by the defendant. The assumption is that with full information we could identify the cases of actual harm; the goal is to concentrate compensation on the defendants who caused that harm.

To take a simple example, suppose that there are two classes containing equal numbers of injured individuals. For members of the first class (Class 1), the probability that the injury was caused by the toxic exposure is $60 \%$; for the second class (Class 2), the probability is $40 \%$. ${ }^{129}$ To minimize the risk of erroneously compensating someone who was not really a victim of the defendant's actions, we should fully compensate members of Class 1 but provide no compensation to members of Class 2. To see this, assume that we transfer a dollar of compensation from a member of Class 1 to a member of Class 2. Do-

the Tort System, 97 HARV. L. REV. 849, 858 (1984) (arguing that "the tort system cannot ... do individualized justice in mass exposure cases under the conventional approach to causality").

${ }^{128}$ The argument for this approach is developed in Daniel A. Farber, Toxic Causation, 71 MINN. L. REV. 1219 (1987). As David Kaye pointed out to me after that article appeared, the proof presented in the article is unnecessarily complicated. A simpler argument, which could be easily formalized in mathematical terms, is presented in the text accompanying note 129 . Also, it should be noted, this solution assumes that the goal is to maximize the amount of funds reaching individuals who were actually harmed by the defendant. If the goal instead is social insurance, a different system might be favored.

${ }^{129}$ The difference might arise because the members of the first class had higher exposures or greater vulnerability, or, alternatively, because the members of the second class have a greater likelihood of acquiring the injury from some other source. 
ing so decreases the probability that the dollar will go to someone actually harmed by the defendant from $60 \%$ to $40 \%$. Hence, payments to members of Class 2 would increase the error rate, and compensation therefore should be entirely focused on Class 1 claimants.

If we assume that the median probability of harm across an entire group is $50 \%$, then this argument provides support for the classic burden of proof rule: those who can show a $51 \%$ probability should receive compensation for all of their injuries, while those who cannot make the threshold showing should receive nothing. Results differ from the classic burden of proof, however, when the median expected harm is not $50 \%$. For example, if the median harm is $30 \%$, then victims with a probability of harm in excess of $30 \%$ should receive full compensation, while those with a probability of harm under $30 \%$ should get nothing.

This model of liability suggests that it may be better to concentrate on full compensation for the most provable harms, rather than to spread funds over all possible victims. Thus, this model provides indirect support for the proposal in this Article that compensation should begin with the most workable subset of climate damages.

\section{Apportionment Among Defendants}

Another problem in toxic tort litigation is establishing a link between a specific defendant and the release of the substance. For example, many hazardous waste generators may have shipped similar materials to the site in question. Establishing ownership of the leaked containers or the quantities they leaked may be quite difficult. A similar issue can arise in products liability cases. In Sindell v. Abbott Laboratories, the plaintiff's mother was administered the drug diethylstilbesterol (DES) during pregnancy. ${ }^{130}$ Although DES was, at that time, routinely given to prevent miscarriage, it is now known to cause a rare form of cancer in some daughters of women who took the drug. After developing that cancer, the plaintiff in Sindell sued eleven of the more than two hundred manufacturers of DES. ${ }^{131}$ Although the plaintiff was unable to identify the manufacturer of the particular DES product that her mother took, the court held that she had stated a cause of action against manufacturers of the drug that all used an identical for-

\footnotetext{
${ }^{130} 607$ P.2d 924 (Cal. 1980).

${ }^{131}$ Id. at $925-26$.
} 
mula. ${ }^{132}$ Resting this holding on a broad social policy, the court noted that the defendants were "better able to bear the cost of injury resulting from the manufacture of a defective product." ${ }^{133}$ The Sindell court then adopted a novel theory of liability by making each defendant liable for a share of the plaintiff's damages, based on the particular defendant's share of the DES market. ${ }^{134}$ Sindell has been followed by a number of other courts, with some variations. ${ }^{135}$

It is obviously impossible to link any specific GHG emissions with any specific injury, due to the cumulative nature of the greenhouse effect. Thus, some form of Sindell-like apportionment seems to be the only workable solution.

Toxic tort litigation illustrates the ways in which compensation efforts can be frustrated when ex post remedies require difficult inquiries into causation. Ex ante remedies such as medical monitoring avoid many of these issues. On the other hand, tort litigation has had some success, particularly in terms of substances like asbestos, which involve large-scale, frequently documented impacts.

\section{CORE COMPENSATION FOR Climate CHANGE}

With the lessons of these analogous compensation systems in mind, I turn to the problem of constructing a compensation system for climate change. The proposal presented here is not particularly ambitious. It limits itself to the most predictable forms of harm and favors the use of the most easily administered measures of damages. Given, however, that no system of compensation exists currently, it seems best to begin with a system that addresses the core of the problem, bearing in mind that even a modest effort at compensation may be politically infeasible.

The proposed definition of compensable climate injuries is based on lessons from other compensation systems. In order to avoid difficult causation inquiries, time lags before compensation, and problems of proof, the proposal stresses ex ante measures of damages such as replacement or substitution costs. It focuses on widespread harms that likely will be capable of standardized assessment, as opposed to

${ }^{132}$ Id. at 928 .

133 Id. at 936.

${ }^{134} I d$. at $936-37$.

${ }^{135}$ A good review of the early cases can be found in In re "Agent Orange" Product Liability Litigation, 597 F. Supp. 740, 820-28 (E.D.N.Y. 1984). Note that the most successful use of the doctrine has been in the highly unusual DES cases. 
highly individualized damage from climate change. Finally, it is amenable to implementation in a number of institutional forms.

\section{A. Policies Favoring Compensation for Climate Damages}

The tort system-and, by extension, other compensation schemes-has several goals. ${ }^{136}$ Probably the two most important are deterring harmful conduct (the efficiency or deterrence rationale) and corrective justice (that is, restoring moral balance by rectifying harm). Loss distribution (which can be considered a way of providing insurance against social risks) is another goal, perhaps more important in social compensation schemes than in tort. A final set of goals is oriented to society as a whole: providing redress for social grievances or exhibiting social solidarity with victims. ${ }^{187}$

Corrective justice involves complex moral issues that are not likely to be resolved simply or to everyone's satisfaction. ${ }^{138}$ Emissions of GHGs were not made with the intent to cause harm to others. Prior to the last quarter of the twentieth century, emitters may not have had strong grounds for believing that their conduct would cause serious harm. Nevertheless, the fact remains that they have caused harm, and in the process they have enjoyed lower costs than they would have incurred by using alternative technologies or by reducing output. Thus, there is a strong element of unjust enrichment, at least in some situations. For those concerned about culpability, apportioning responsibility on the basis of emissions after some cutoff date would be an appropriate response. One possible cutoff date is 1992, when the United States and other nations entered a framework agreement to reduce GHGs. ${ }^{139}$ At that point, the international community had

${ }^{136}$ For a general discussion of the tort system's goals, see KENNETH S. ABRAHAM, THE FORMS AND FUNCTIONS OF TORT LAW 14-20 (2d ed. 2002).

${ }^{197}$ For an insightful discussion of this solidarity rationale in the context of catastrophic natural events, see Stephen D. Sugarman, Roles of Government in Compensating Disaster Victims, ISSUES IN LEGAL SCHOLARSHIP, 2007, art. 1, at 28-31, available at http://www.bepress.com/ils/iss10/artl.

${ }^{138}$ Matthew Adler's thoughtful commentary on this Article explores these issues in more depth. His analysis suggests that the climate change situation may be an imperfect fit with philosophical theories of corrective justice, although it appears that the philosophical case for compensation at the international level seems stronger than at the local level. See Matthew D. Adler, Corrective Justice and Liability for Global Warming, 155 U. PA. L. REV. 1859, 1865-67 (2007).

139 See Brown, supra note 3, at 10,741 (analyzing "the extent to which the United States has advanced in meeting sustainable development commitments made in Rio de Janeiro in 1992"). 
clearly identified the harm; any source of emissions after that date was at least on notice of the damaging nature of the conduct.

It may be premature to make a judgment about the culpability of GHG emitters. At the very least, it seems arguable that at some point it became negligent not to take reasonable precautionary measures to reduce emissions. Given the amount of misinformation that has been spread by industry-sponsored groups, as well as efforts within the U.S. government during the past six years to suppress information, there is also at least the possibility of deliberate misrepresentations, as turned out to be the case in the tobacco industry concerning the risks of cigarettes. ${ }^{140}$ At this point, it is impossible to know whether there was a deliberate campaign of deception, but pre-trial discovery in one of the nuisance cases, or intensive congressional hearings on related issues, might shed light on the subject. Given the amount of money to be gained in some industries by forestalling any serious response to climate change, it would not be surprising to discover cases of deliberate deception of the public or improper pressure on governments.

In terms of the deterrence goal of compensation, it is obviously impossible to deter conduct that has already taken place. Nevertheless, establishing a rule that requires compensation for past emissions can provide a precedent for future liability schemes that cover other emerging environmental harm. For example, the fear that another country might emulate CERCLA liability provides an incentive for care in disposing of hazardous waste, even if that country in which disposal occurs does not currently have a stringent regulatory scheme. Thus, the possibility of retroactive liability can provide useful incentives to avoid novel forms of harmful conduct. ${ }^{141}$ In the absence of

${ }^{140}$ Consider, for example, a memo leaked from the American Petroleum Institute about a campaign to indoctrinate science students and teachers about the alleged uncertainties of climate research in order to impede efforts such as Kyoto. See Laurie David, Science a la Joe Camel: An Inconvenient Truth About One American Teachers Association, S.F. CHRON., Dec. 10, 2006, at C4 (describing the American Petroleum Institute's efforts to tout its environmental track record while challenging global warming). Notably, the National Science Teachers' Association declined to distribute copies of Al Gore's An Inconvenient Truth because it considered the film to be "political" and because doing so might imperil the association's capital campaign. ExxonMobil has been a strong supporter of the association. Id.

${ }^{141}$ It is also arguable that the liability would not be truly retroactive. As the $R e^{-}$ statement drafters note, the "abnormally dangerous doctrine has a significant application in the context of environmental harms," including application to activities, such as toxic waste handling, that are not at all uncommon in our economy. RESTATEMENT (THIRD) OF TORTS: LIAB. FOR PHYSICAL HARM $\$ 20 \mathrm{cmt}$. k reporters' note (Proposed Final Draft No. 1 2005). Applying strict liability to the production of GHGs arguably 
such a liability threat, when new environmental issues arise, those producing the harms will assume that they have a free ride until a liability scheme that deals specifically with the new problem is put into effect. This would discourage early efforts to reduce harmful conduct. $^{142}$ Thus, a general policy of retroactive liability for environmental harm might have valuable deterrent effects.

This deterrence rationale has some inherent limitations. The deterrence rationale clearly does not apply before the point when the harmful nature of the conduct could reasonably have been discovered, and it applies with the greatest force to activities whose harmful nature has already become clear. Moreover, once an effective regulatory scheme is in place, liability for further emissions may not serve a useful deterrent function. But potential liability may provide useful incentives in the period between the discovery of the harmful environmental effect and the implementation of an appropriate regulatory scheme.

Loss distribution seems to be most significant in two situations: (1) where the precise incidence of the harm is unknown, but the private market cannot provide insurance (the insurance function); and (2) where the victims of harm are markedly poorer than those causing the harm (income redistribution). The income redistribution function is probably strongest at the international level, where relatively affluent nations, like the United States, are heavy emitters, and impacted victims are poorer countries, such as Bangladesh. As the Stern Review says,

[t] he poorest in society are likely to have the least capacity to adapt .... Given that the greatest need for adaptation will be in low-income countries, overcoming financial constraints is also a key objective. This will involve transfers from rich countries to poor countries. The argument is strongly reinforced by the historical responsibility of rich countries for

could be justified on this basis, or on the basis of public nuisance law (as invoked in People ex rel. Lockyer v. General Motors Corp., discussed supra note 34 and accompanying text).

These concerns suggest an alternative way of measuring damages. Under section $120(d)(2)$ of the Clean Air Act, 42 U.S.C. $\$ 7420$ (d)(2) (2000), air polluters are assessed a penalty for noncompliance in the amount of the economic value of noncompliance. Regulations implementing this provision were upheld in Duquesne Light Co. v. EPA, 698 F.2d 456, 461-62 (D.C. Cir. 1983). By removing this economic benefit, the noncompliance penalty eliminates the incentive to delay compliance and also prevents firms from obtaining an unfair advantage over competitors who have chosen to comply promptly. By analogy, entities that have failed to take timely steps to reduce GHG emissions could be assessed on the basis of the economic benefits they have attained from the delay. 
the bulk of accumulated stocks of GHGs. Poor countries are suffering and will suffer from climate change generated in the past by consumption and growth in rich countries.

The insurance function is probably most appropriate for the harms caused by extreme weather events, such as hurricanes, in which the victims' identities are inherently unpredictable. The case for insurance is weaker when harms are more predictable, such as the impact of graduated sea level changes on coastal areas.

Finally, the societal aspects of compensation must be considered. Within the United States, at least, there is some argument for expressing solidarity with fellow citizens who are suffering distinct harm because of widespread national practices. For some, a similar sense of solidarity may extend more globally. The potential social conflicts resulting from climate change also need to be considered. Individuals who suffer loss or displacement due to climate change are likely to be angry and resentful. This effect could be potentially destabilizing in some parts of the world, posing threats to international and U.S. security. Within the United States, such effects are likely to be more muted, but could still lead to political animosity and polarization.

It is also worth noting that the United States and other countries have already agreed in principle to take some responsibility for adaptation measures in less developed countries. Article 4.4 of the United Nations Framework Convention on Climate Change states that "developed country Parties and other developed Parties included in Annex II shall also assist the developing country Parties that are particularly vulnerable to the adverse effects of climate change in meeting costs of adaptation to those adverse effects." ${ }^{144}$ Article 4.1(e) also calls on countries to "[c]ooperate in preparing for adaptation to the impacts of climate change"; countries are also directed to "develop and elaborate appropriate and integrated plans for coastal zone management, water resources and agriculture, and for the protection and rehabilitation of areas, particularly in Africa, affected by drought and desertification, as well as floods." ${ }^{145}$ This cooperation mandate amounts to a requirement of in-kind contribution to adaptation measures. Thus, at least in principle, the United States and other signatories to the framework agreement already seem to have agreed to

${ }^{143}$ STERN, supra note 1 , at 37.

${ }^{144}$ U.N. Framework Convention on Climate Change, art. 4.4, May 9, 1992, available at http://unfccc.int/resource/docs/convkp/conveng.pdf.

${ }^{145}$ Id. art. $4.1(\mathrm{e})$. 
compensation at the international level. It is also worth noting that the parties to the Kyoto agreement have embraced the use of an adaptation fund, which is financed by a share of the proceeds generated by the Clean Development Mechanism. ${ }^{146}$

On balance, there seems to be a good case for climate change compensation-assuming that a reasonably efficient compensation mechanism can be designed. Clearly, some people have profited from the absence of GHG limitations well after the need for such limits became clear. Their conduct will cause long-term harm to others. In order to provide redress to the victims and provide an incentive for care in dealing with other emerging environmental problems, compensation is warranted. The argument for compensation seems to be strongest as applied to conduct that takes place after the harms of climate change are identified (so that emitters are on notice) but before effective regulatory controls are in place (which would itself create deterrence).

Although compensation is supported by some strong policy arguments, one serious concern needs to be addressed. That concern is that emphasizing compensation poses the risk of undermining efforts to mitigate and adapt to climate change. This interference could stem from either political or economic factors.

One political concern is that compensation claims could be polarizing, making it more difficult to reach agreements on mitigation measures. It may be hard enough to get emitters to agree to future restrictions without also requiring them to accept liability for past conduct. This effect is not implausible, but it does seem rather speculative. It seems equally likely that the potential availability of compensation would drive emitters to the bargaining table earlier, discouraging them from holding out over mitigation measures. Alternatively, the availability of compensation might reduce pressure from victims for stringent mitigation measures that emitters find unacceptablethereby smoothing negotiations.

A related economic issue involves the potential effect of large transfer payments. It is not possible to calculate the full harm caused by climate change, but there is no doubt that it involves a very large amount of money. Diverting massive financial resources to compensa-

146 See Dean Scott, U.N. Climate Talks Make Some Progress on Adaptation, Joint Imple mentation, 29 INT'L ENV'T. REP. 867, 867 (2006) (explaining that the adaptation fund agreement "lays the groundwork for project funds to begin flowing to developing nations"). 
tion might leave too little for adaptation or mitigation. This is a potentially serious concern, but there are several ways of dealing with it.

First, it might not make sense to try to provide complete compensation for climate-related harms. The wider the sphere of compensable harms, the greater the problems of proof and the greater the administrative expense of providing compensation. This is one argument for at least beginning with a more manageable set of harms. Moreover, restricting the set of compensable harms also serves to keep the scope of liability within manageable limits. In addition, it may prevent politically and socially disruptive effects such as widespread bankruptcies or plant closings.

Second, in terms of adaptation, the easiest way to prevent compensation payments from causing interference is by tying compensation to adaptation projects. For example, possible adaptations for harms relating to sea level change could include building sea walls, where appropriate, or providing substitute wetlands through restoration projects. One precedent for this approach is provided by the UNCC compensation system discussed earlier. ${ }^{147}$ Creating such a tie ensures that funds are not diverted from needed adaptation measures into current consumption.

Third, in terms of mitigation, there may be ways to ensure that compensation does not detract from emissions reduction or other measures, such as the creation of carbon sinks. If mitigation is achieved through a cap-and-trade system, we might want to provide compensation by reallocating some emissions allowances from emitters to victims. Victims would receive financial compensation by selling allowances, which emitters would have to acquire for compliance purposes. ${ }^{148}$

Thus, the potential for interference with forward-looking measures seems to be manageable by restricting the class of compensable harms and carefully designing payment mechanisms. Putting this issue aside, the case for compensation is at its strongest when (1) emitters are on notice of the harmful nature of their conduct, (2) an optimum regulatory scheme is not in place at the time of the emissions, (3) the class of compensable harms is not so broad as to create overwhelming financial burdens, (4) claimants do not have the benefit of

147 See supra Part II.B.

${ }^{148}$ If a carbon tax is the primary form of emissions control, then compensation could be financed from the tax revenues, or emitters could be given a tax offset for compensation payments. 
private or social insurance, (5) victims are significantly poorer than emitters, and (6) the payment system is tied to the systems for mitigation and adaptation. This is not to say that these are necessary conditions or that an ideal compensation system would not be substantially broader. These parameters do, however, seem to identify the most favorable circumstances for compensation.

Some readers may remain unconvinced that compensation is warranted even when all or most of the six conditions are met. Those readers should, however, agree with the judgment that these conditions present the strongest cases for compensation on a relative scale, even if they do not cross the threshold of acceptability on an absolute scale. Skeptical readers should regard the remainder of this Article as the answer to a hypothetical question: if we did want to adopt a system for compensating climate change, what would be the optimal characteristics of that system?

\section{B. Defining Core Compensable Harm}

The definition of compensable harm has several objectives. It should minimize the problems of proof and proximate cause that plague toxic torts cases. It should also be broad enough to provide significant relief to victims, but not so all encompassing as to create overwhelming financial burdens and thereby distract from climate change mitigation or other desirable social goals. A compensation system will also be more acceptable to the extent that it adopts features of existing compensation schemes.

Given these goals, one desirable measure of harm is based on reasonable monitoring and adaptation expenditures. Awarding compensation for such preventive measures is supported by the following sources: U.S. toxic tort law as it relates to medical monitoring expenses; ${ }^{149}$ UNCC practice, in its use of adaptation measures and the cost of providing alternate ecosystem services; ${ }^{150}$ and the preference for replacement damages under CERCLA and other schemes. ${ }^{151}$

Using restoration, adaptation, and precaution as the default measures of damages also avoids the difficulty of determining, ex post, whether an injury to a particular claimant was the result of climate change. It is easier to show that increases in extreme weather events

\footnotetext{
149 See supra Part II.F.1.

${ }^{150}$ See supra Part II.B.

${ }^{151}$ See supra text accompanying notes 71-100.
} 
require higher levees than it is to show that a particular house was damaged in a flood due to climate change. As the U.S. toxic tort cases show, it is difficult to assess causation in the presence of scientific uncertainty.

These measures of damages also focus compensation in the areas where harm is most foreseeable, and hence on the entities that are most likely to be victims. As discussed earlier in connection with toxic torts, compensating the most likely victims rather than spreading compensation across all possible victims minimizes error costs. ${ }^{152}$ If we identify adaptation projects required by climate change, we can be confident about entitlement to compensation in a way that is unlikely where ex post damages are concerned.

\section{Possible Institutional Forms}

The primary purpose of this Article is to identify the types of injuries that should be given priority in compensating for climate change. A further question is, what sort of institutional framework should be used for assessing damages, awarding compensation, and funding the awards? A detailed discussion of this question is beyond the scope of this Article. It is important to observe, however, that there are several possible institutional frameworks. Hence, it should not be assumed that compensation will be delivered through damage awards from lawsuits or some other specific mechanism. Each of the potential mechanisms has advantages and disadvantages.

\section{Litigation}

Litigation is the most obvious way to procure compensation. Claims in the U.S. courts involving damage to natural resources, whether based on tort law or statutes such as CERCLA, provide one possible model for such a system.

At present, international tribunals are unlikely to be able to compel payment of large judgments, even if they take jurisdiction. Domestic courts have greater coercive power. They may be able to handle some international disputes, assuming defendants are local nationals or have sufficient local assets to be within the court's jurisdiction and amenable to meaningful relief. They may also be natural forums for domestic compensation disputes. 
The great advantages of courts are their political independence, their obligation to make principled decisions, and their engagement with concrete disputes over injuries. Ideally, these characteristics may allow courts to make socially desirable decisions that the political system is unable to produce. The major disadvantages of courts are their lower degree of democratic legitimacy, their possible reluctance to engage in large-scale innovation, and their inability to produce a comprehensive compensation system.

Realistically, the greatest function of litigation may be to prod legislative action. A number of legislative compensation schemes, such as the 9/11 fund, seem to have come into existence as a way of forestalling litigation against key private entities.

\section{Administrative Adjudication}

A legislatively established administrative system would offer several advantages over courts. ${ }^{153}$ It could operate under a more comprehensive set of rules. In addition, transaction costs could be lower because agency expertise would produce more efficient decisions. It might also be easier for an agency to produce standardized protocols and payment schedules, which would simplify the adjudicatory process.

One model for such an administrative process would be the UNCC. As described earlier, the UNCC handled adjudication of environmental damage claims after the first Gulf War. ${ }^{154}$ It seems to have handled the claims reasonably efficiently and with general procedural fairness.

An administrative system would also have disadvantages, however. First, such a system would require legislative action (or an international treaty), which might not be forthcoming or could be flawed by interest group politics. Second, administrative compensation systems seem to have difficulty remaining current in terms of compensation levels. Third, greater efficiency will probably result in less accurate decision making in individual cases. Finally, the adjudicatory process might be subject to political pressure, making decisions unreliable.

${ }^{153}$ The issues involved in designing such a system are discussed in Robert $\mathbf{L}$. Rabin, Some Thoughts on the Efficacy of a Mass Toxics Administrative Compensation Scheme, 52 MD. L. REV. 951, 964-78 (1993). Additionally, a sketch of one such system is offered in the Introduction to this Article.

${ }^{154}$ See supra Part II.B. 


\section{Grants}

Rather than relying on adjudication, a compensation system could be based on an assessment system against responsible parties in order to establish a fund, which would then be disbursed in a grant-making process. Such a fund could be established as a litigation settlement, through legislative, administrative, or international processes, or even through voluntary action. For example, countries with high emissions could make payments to the World Bank, which could then make grants to finance adaptation measures elsewhere in the world. In the private sector, individual businesses or groups of like-minded businesses with high emissions histories could make similar grants, perhaps with some government encouragement in the form of favorable tax treatment.

These grants would not need to be accompanied by any admission of liability, but could instead be considered a voluntary acceptance of responsibility for past acts. Such actions might resemble the kind of reparations sought by some advocates for past activities, such as corporate complicity with slavery. ${ }^{155}$ There are obviously limits to how much we can expect in the way of voluntary action, but it is easy to imagine various motivations beyond ethical responsiveness that might be operative. Such additional motivations might include the desire to project a good image to customers (or voters) and employees, to establish friendly relations with countries and communities suffering damage from climate change, and to forestall coercive compensation efforts (or at least accumulate credits against later compensation demands). ${ }^{156}$

The disadvantage of the grant system is that it decouples financial contributions from determinations of damages. Contributions are likely to be based primarily on either their acceptability to the grantors or as part of a deal between grantors and grantees. Total payments probably would fall well short of compensable harm. More-

${ }_{155}^{155}$ See, e.g., supra text accompanying note 115.

${ }^{156}$ One feature of the compensation system that has to be addressed is whether voluntary transfers should offset compensation requirements. It seems plausible that they should, but it may be difficult to define precisely which payments count as sufficiently related to specific compensable harms. Relatedly, the "collateral source" issue needs to be addressed: to what extent do payments from third parties offset compensation that would otherwise be due? For example, it is not clear whether, to the extent insurance is available for compensable harms, the insurance should be an offset, or whether, on the other hand, the insurance company should just subrogate to the rights of the insured. 
over, any incentive effect is likely to be lost; the parties most in need of an incentive to mitigate emissions are also probably the least likely to make voluntary contributions. Another risk of decoupling is shown by the United States's bio-prevention compensation scheme (PREPA), which lacks guaranteed funding. ${ }^{157}$ On the other hand, decoupling produces a less adversarial process for issuing funds, which could lead to faster relief for the injured parties.

An advantage of the grant system is that it could be directed at the victims with the greatest need-those with the fewest resources and the most urgency to adapt. From a social welfare perspective, payments to those victims would produce the greatest benefit without the expense of attempting to deal with less urgent compensation cases.

\section{Declaratory Relief}

Strictly speaking, declaratory relief is not a compensation system at all, but there is something to be said for at least establishing a trustworthy system for assessing core damages and allocating responsibility to emitters, even in the absence of any provision for payment. Such a system would put pressure on emitters to engage in voluntary transfer payments. It would also help highlight and particularize the harm done by climate change, thereby encouraging the adoption of mitigation measures. Also, to use a phrase currently en vogue in Washington, it might at least produce a degree of "moral clarity" about responsibility for harm.

In the field of reparations, such allocations of responsibility take the form of truth commissions, such as that in South Africa. Some people believe that, by acknowledging the existence of victimhood and responsibility, such truth commissions can play a socially integrative role, paving the way for a more just society. ${ }^{158}$

Because anger at GHG emissions is not likely to be targeted at particular individuals, some of the reparative functions of truth commissions are unlikely to be served. Moreover, individual victims will not be easily identifiable. Thus, the "truth commission" idea may not have

157 See supra note 53.

${ }^{158}$ For discussions of truth commissions and their role in transitional justice, see MARTHA MINOW, BETWEEN VENGEANCE AND FORgIVENESS: FACING HiSTORY AFTER GENOCIDE AND MASS VIOLENCE 57 (1998) ("If the goal of healing individuals and society after the trauma of mass atrocity is elevated, truth commissions could well be a better option than prosecutions."); MARK OSIEL, MASS ATROCITY, COLlECTIVE MEMORY, AND THE LAW 271 (1997) (listing truth commissions as one of several ways that states can respond to a "popular upsurge of demand for the facts"). 
the same potential for healing as advocates claim it has in some other contexts. Nevertheless, identifying responsibility for burdens placed on other regions may still be helpful in setting the stage for negotiations or other compensation mechanisms.

\section{Contributory Fault and Related Issues}

Nearly everyone on the planet, in some small way, contributes to the generation of GHGs. Some contribute more than others, but in nearly every case, it is at least possible to imagine that the claimant's personal conduct might be used as a basis for avoiding or reducing compensation. In other words, the claimant's own activities may be relevant to the availability or amount of compensation. This argument can play out in several different ways.

\section{Contributory Fault}

In some situations, the injured parties will themselves have made significant contributions to causing climate change. This is unlikely to be true for the poorest of communities, which lack the resources to produce high levels of GHGs. But especially for claims within the United States, such contributions to climate change should be taken into account.

In practice, this should not be difficult to do. The percentage of world GHG emissions produced by the claimant could be used as a multiplier, with that proportion of the compensation claim being reduced. Alternatively, the deduction could be based on the amount of emissions over the optimum control level for the claimant, so that claimants who took feasible steps to reduce emissions would receive a greater reward. Except for the very largest emitters, it should make little difference which offset is used, since the claimant's emissions will be insignificant compared to the global level. Even a claimant who produced a very large amount of GHGs-say ten percent of the world total-would receive ninety percent payment on claims.

Simply to reduce administrative costs, it might be useful to preclude claims by large emitters whose share of GHGs is larger than their share of climate damages. Doing so would tend to eliminate cases in which major emitters are simply passing funds around between each other at some administrative expense. Such a rule would be analogous to a common variant of the contributory fault system in 
the United States in which parties who are more than fifty percent at fault for an accident cannot recover. ${ }^{159}$ At the international level, for example, claims between the United States and China might be largely offsetting, and hence it might be easier simply to eliminate them from consideration.

There are several arguments against eliminating claims by large emitters. First, there might be considerable dispute about where to draw the line. Second, emitters of equal size might not be equally at fault. Third, one emitter might be much more vulnerable to climate change than the other, so the damages would not be offsetting. On balance, having a special rule for large emitters is probably not advisable, but the problem deserves further consideration.

\section{Offsets for Climate Change Benefit}

Climate change is likely to produce local benefits in some regions in the form of less rigorous winters, more optimal levels of precipitation, or longer growing seasons. Should there be an offset for such benefits in the compensation system?

The answer is probably no, because the compensation system covers only a portion of damages. The core compensation system proposed in this Article excludes many kinds of damages, but even a compensation system that attempted to be comprehensive would be very unlikely to provide full compensation. The costs of climate change are simply too systemic and difficult to trace. Hence, whatever benefits are obtained from climate change may well be countered by uncompensated damages. Given the additional problems of proof and administrative costs in establishing offsets for climate change benefits, the case for doing so appears weak. A perfect system would surely include all costs and all benefits experienced by the claimants, but such a system is probably too complex to be manageable. A better solution is to provide full compensation for a subset of harms, while assuming that the remaining harms are likely to be at least as high as any benefits. It might be worthwhile, however, to exclude claimants that have experienced significant net benefits from climate change.

159 See ReSTATEMENT (THIRD) OF TORTS: LiAB. FOR PHYSICAL HARM $\S 25 \mathrm{cmt}$. d reporters' note (Proposed Final Draft No. 1 2005) (“[M]any states . . have adopted comparative responsibility in a modified form, pursuant to which the plaintiff's contributory negligence continues to operate as a full defense if it is greater than the defendant's negligence."). 
Those entities could be reasonably expected to use their benefits as a source of funding for adaptation measures.

\section{Moral Hazard}

As the U.S. flood insurance program indicates, one unfortunate side effect of a compensation scheme can be to reduce the incentive for risk-avoiding behavior. ${ }^{160}$ Similarly, a compensation system could reduce incentives to relocate vulnerable populations, or it could lead to overinvestment in preventive measures, such as sea walls to combat sea level change. One possible solution, which was attempted in the flood insurance program, is to couple compensation with acceptance of regulatory restrictions. This has been, at best, a partial success. ${ }^{161}$

Another option is to impose a duty to mitigate damages on injured parties. This would involve making an independent assessment of whether mitigation measures are reasonably necessary in light of alternatives or whether the injured party unduly exposed itself to risk. The UNCC process provides a model here. ${ }^{162}$ In principle, this system provides a complete solution. In practice, of course, it increases the complexity and expense of proceedings, as well as the risk of error.

Dealing with moral hazard problems is part of the larger question of how to efficiently establish damages. In an administrative setting, the best solution might be to devise a schedule of presumptive adaptation expenses, and to give a limited opportunity for either side to introduce evidence of special circumstances.

\section{Proof of Damages}

Individualized proof of damages may be complex and difficult, especially if the proof requirement includes evidence of mitigation. One response would be to create a schedule of damages, as was done with the $9 / 11$ fund. ${ }^{163}$ This would provide for a standardized method of assessing, for example, the value of property lost to sea level rise, the reasonable cost of additional levees and sea walls, or the cost of

\footnotetext{
${ }^{160}$ See supra text accompanying note 103 . In the case of flood insurance, too much insurance may lead to undesirable construction in flood-prone areas.

${ }^{161}$ Concerns about the effectiveness of the regulations are discussed in Congressional Research Service, supra note 102, at 19-24.

${ }^{162}$ See supra note 58 and accompanying text.

${ }^{163}$ See supra text accompanying notes 48-52.
} 
providing compensating benefits through wetlands creation. It would also address the mitigation issue discussed above.

In practice, such scheduling seems necessary because of the high number of damage claims. A damages schedule is unlikely to be perfectly accurate, because it will reflect a compromise between precision and administrability. As a result, it may lead to under- or overcompensation. Either mistake has clear fairness implications, and might also create insufficient incentives for emissions controls or some degree of moral hazard for victims. But workability is probably more important in this context than precision.

There is a natural tendency to want to fine tune the system in order to come as close as possible to the optimum level of compensation. This would be a mistake. Determining exactly the right level of compensation in every case would be extremely expensive and time consuming. It would waste expertise that could be more usefully employed to design mitigation and adaptation measures. It would also probably delay compensation to the point of diminishing its value to victims. It is better to have a rough and ready system of compensation that provides at least partial justice and operates efficiently.

\section{CONCLUSION}

This Article assumes that GHG emissions will have damaging climatic effects. Even given the improbable assumption that the world will adopt an optimal policy to mitigate further emissions, some harmful impacts are unavoidable. Whether to provide compensation for these damages is a complex, difficult question, as is how to design a system for doing so. This Article makes no claim to have settled these issues. Rather, my goal has been to provide some context for considering the issues, to indicate something about the range of possible solutions, and to put forward one possible model for awarding compensation.

The proposed model focuses on the impact of climate change on geographic features such as coastlines, wetlands, glaciers, permafrost, rivers, and lakes. Widespread impacts on these features are already underway, so these effects are far from speculative. As a preferred measure of damages, I suggest the cost of remedial measures such as monitoring, protecting, restoring, or providing substitutes for existing resources. There is precedent for such ex ante measures of damages in U.S. laws governing oil spills and hazardous waste releases, in the United Nations Compensation Commission's effort to provide com- 
pensation for environmental harm after the first Gulf War, and in medical monitoring recoveries in toxic torts laws.

The alternative to this ex ante compensation is to provide compensation ex post, based on proof of actual damages from changes in climate and weather. One difficulty with this alternative is that it spreads compensation over decades, if not centuries. Another is that it raises difficult issues of causation and complicated problems of valuation. The ex ante approach delivers compensation earlier, more efficiently, and with less uncertainty.

Such a scheme could be implemented in many institutional forms. It could be the basis for liability determinations by domestic courts or international tribunals. Alternatively, an administrative compensation scheme might be used. The system could be given a more voluntary dimension through agreements by responsible parties to finance grants for remedial measures (perhaps as litigation settlements or with the encouragement of either tax benefits or subsidies).

This is a fairly modest proposal, firmly grounded in existing compensation practices. It leaves unaddressed many other forms of injury from climate change. But the difficulties of establishing any compensation system at all are formidable. It is better to begin with something unambitious and manageable than to aim for a possibly unattainable ideal. Climate change and its impacts will be with us for the foreseeable future. There will be plenty of time to consider the possibility of expanding the system. The priority for now is simply to put the outline of a workable alternative on the table. 